Prepared in cooperation with the Nevada Division of Environmental Protection

\title{
Discharge Data Collection and Analysis and Implications for Surface-Water/Groundwater Interactions in the lower Las Vegas Wash, Clark County, Nevada, 2016-18
}
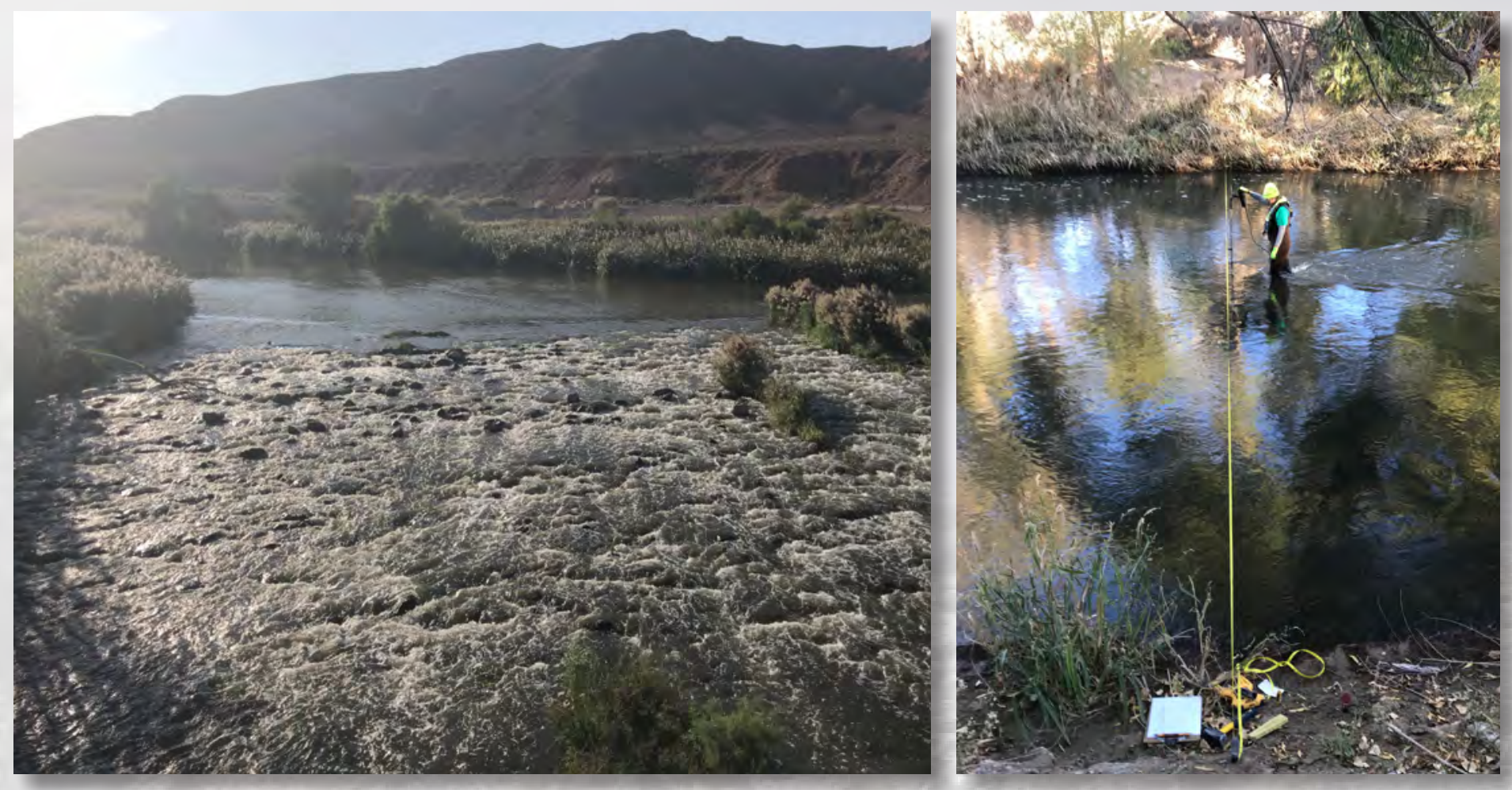

Scientific Investigations Report 2021-5034 
Cover (left): Photograph looking west from foot bridge above Powerline Crossing Weir. Photograph taken by Jon W. Wilson, U.S. Geological Survey, October 18, 2017.

Cover (right): Photograph of U.S. Geological Survey hydrologist Katherine Earp collecting a discrete measurement at site I-5. Photograph taken by Jon W. Wilson, U.S. Geological Survey, December 8, 2017. 


\section{Discharge Data Collection and Analysis and Implications for Surface-Water/ Groundwater Interactions in the lower Las Vegas Wash, Clark County, Nevada, 2016-18}

By Jon W. Wilson

Prepared in cooperation with the Nevada Division of Environmental Protection

Scientific Investigations Report 2021-5034 


\section{U.S. Geological Survey, Reston, Virginia: 2021}

For more information on the USGS - the Federal source for science about the Earth, its natural and living resources, natural hazards, and the environment—visit https://www.usgs.gov or call 1-888-ASK-USGS.

For an overview of USGS information products, including maps, imagery, and publications, visit https://store.usgs.gov/.

Any use of trade, firm, or product names is for descriptive purposes only and does not imply endorsement by the U.S. Government.

Although this information product, for the most part, is in the public domain, it also may contain copyrighted materials as noted in the text. Permission to reproduce copyrighted items must be secured from the copyright owner.

Suggested citation:

Wilson, J.W., 2021, Discharge data collection and analysis and implications for surface-water/groundwater interactions in the lower Las Vegas Wash, Clark County, Nevada, 2016-18: U.S. Geological Survey Scientific Investigations Report 2021-5034, 25 p., https://doi.org/10.3133/sir20215034.

Associated data for this publication:

Wilson, J.W., 2021, Trace of the lower Las Vegas Wash study area, 2017: U.S. Geological Survey data release, https://doi.org/10.5066/PgUOCOSM.

ISSN 2328-0328 (online) 


\section{Contents}

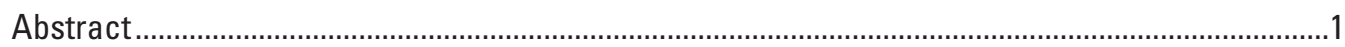

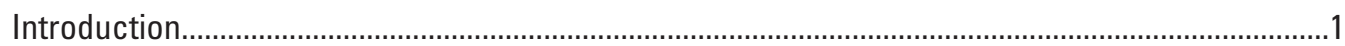

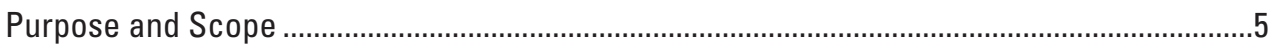

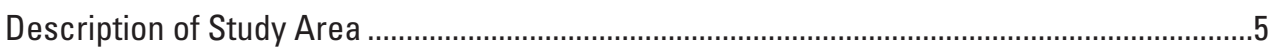

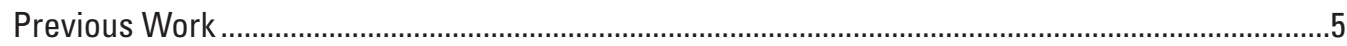

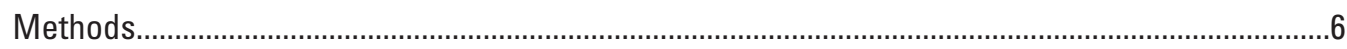

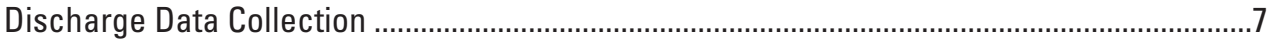

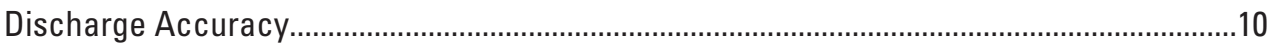

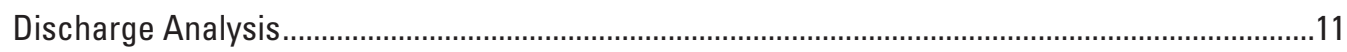

Water Year 2017 and 2018 Discharge Variation .......................................................................

Seasonal Discharge Variations ..........................................................................................12

Daily Discharge Variations Between Gaging Stations ...........................................................12

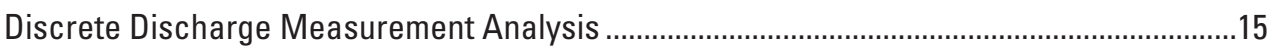

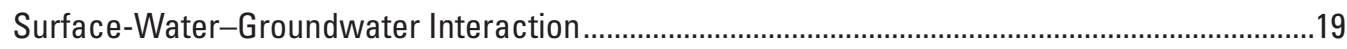

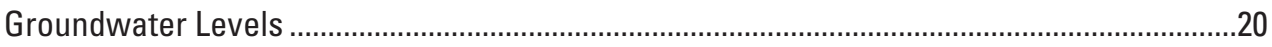

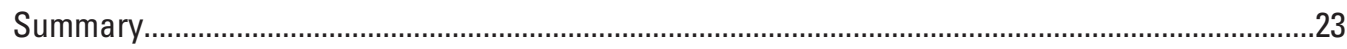

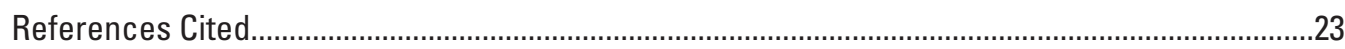

\section{Figures}

1. Map showing location of Nevada Environmental Response Trust and lower Las Vegas Wash study areas in Clark County, Nevada ............................................................2

2. Graph showing population of Clark County and average annual discharge at the lower Las Vegas Wash, Clark County, Nevada, 1957 to 2017.......................................3

3. Map showing location of U.S. Geological Survey gaging stations, grade-control weirs, and surface-water inflow along the lower Las Vegas Wash surface-water data-collection boundary, Clark County, Nevada ........................................

4. Diagram showing discharge gaging station and discrete measurement site locations and distances between measurement sites along the lower Las Vegas Wash and tributary inflow, Clark County, Nevada

5. Graph showing comparison of discharge records for Pabco and Above Three Kids Wash stream gages showing the average time-lag between peak and minimum flows, lower Las Vegas Wash, Clark County, Nevada....

6. Graph showing comparision of interpolated discrete hydrograph and time-adjusted continuous discharge hydrograph from Above Bostick Weir, measured on June 8, 2017, lower Las Vegas Wash, Clark County, Nevada

7. Graph showing monthly mean discharge at Pabco and Above Three Kids Wash gaging stations from January 2005 to June 2018

8. Diagram showing yearly average discharge in cubic feet per second at U.S. Geological Survey gaging stations for water years 2017 and 2018, and associated gain to or loss from bank sediments by reach, lower Las Vegas Wash and tributary inflow, Clark County, Nevada

9. Graph showing cumulative change in average monthly discharge at Reaches 1 , 2, 3, and 4, lower Las Vegas Wash, Clark County, Nevada. 
10. Graph showing average monthly discharge difference at Reaches No. 1, 2, 3, and 4, lower Las Vegas Wash, Clark County, Nevada.....

11. Graph showing average seasonal discharge at U.S. Geological Survey gaging stations in the lower Las Vegas Wash, Clark County, Nevada..

12. Graphs showing daily diurnal stream discharge record for U.S. Geological Survey surface-water gaging stations and associated stream reach, lower Las Vegas Wash, Clark County, Nevada ....

13. Graph showing stream discharge (left y-axis) and difference in stream discharge (right y-axis) for downstream and upstream gages defining Reach No. 4, lower Las Vegas Wash, Clark County, Nevada.

14. Graph showing average daily difference in discharge record at Reach No. 1, No. 2, No. 3, and No. 4, lower Las Vegas Wash, Clark County, Nevada.

15. Diagram showing discharge gain and loss for reaches and subreaches along the lower Las Vegas Wash, Clark County, Nevada.

16. Graph showing approximate surface-water and groundwater longitudinal profiles from water-level altitudes at USGS gaging stations, discrete measurement sites, and nearby wells, lower Las Vegas Wash, Clark County, Nevada

17. Map showing location of Nevada Environmental Response Trust monitoring wells, lower Las Vegas Wash, Clark County, Nevada

18. Hydrographs of stage for Duck Creek Confluence gaging station, Reaches No. 2 and 4, and water levels in selected NERT wells, June 3-June 6, 2017, lower Las Vegas Wash and tributary inflow, Clark County, Nevada

\section{Tables}

1. Average lag in streamflow travel time between U.S. Geological Survey gaging stations and discrete measurement sites along the lower Las Vegas Wash, Clark County, Nevada. Discrete and continuous discharge measurement locations are shown on figure 4

2. Summary of gaging stations and discrete measurement locations along the lower Las Vegas Wash, Clark County, Nevada.

3. Summary of the number of discrete discharge measurements made during synoptic data-collection events along the lower Las Vegas Wash, Clark County, Nevada

4. Summary of discharge from tributary inflows to lower Las Vegas Wash above U.S. Geological Survey gage at Pabco, and sources of data for treated groundwater and wastewater, lower Las Vegas Wash, Clark County, Nevada.

5. Change in discharge at select reaches along the lower Las Vegas Wash, Clark

County, Nevada

6. Altitude of surface water at U.S. Geological Survey gaging stations from Global Navigation Satellite Systems (GNSS) survey conducted March to June 2018, lower Las Vegas Wash, Clark County, Nevada. 


\section{Conversion Factors}

U.S. customary units to International System of Units

\begin{tabular}{lcl}
\hline & Multiply & \multicolumn{1}{c}{ Bo obtain } \\
\hline foot $(\mathrm{ft})$ & Length & \\
mile $(\mathrm{mi})$ & 0.3048 & meter $(\mathrm{m})$ \\
& 1.609 & kilometer $(\mathrm{km})$ \\
\hline acre & Area & \\
acre & 4,047 & square meter $\left(\mathrm{m}^{2}\right)$ \\
acre & 0.4047 & hectare $($ ha) \\
acre & 0.4047 & square hectometer $\left(\mathrm{hm}^{2}\right)$ \\
square mile $\left(\mathrm{mi}^{2}\right)$ & 0.004047 & square kilometer $\left(\mathrm{km}^{2}\right)$ \\
square mile $\left(\mathrm{mi}^{2}\right)$ & 259.0 & hectare $($ ha) \\
\hline & 2.590 & square kilometer $\left(\mathrm{km}^{2}\right)$ \\
\hline cubic foot $\left(\mathrm{ft}^{3}\right)$ & Volume & \\
cubic foot $\left(\mathrm{ft}^{3}\right)$ & 28.32 & cubic decimeter $\left(\mathrm{dm}^{3}\right)$ \\
acre-foot $(\mathrm{acre}-\mathrm{ft})$ & 0.02832 & cubic meter $\left(\mathrm{m}^{3}\right)$ \\
acre-foot $(\mathrm{acre}-\mathrm{ft})$ & 1,233 & cubic meter $\left(\mathrm{m}^{3}\right)$ \\
\hline & 0.001233 & cubic hectometer $\left(\mathrm{hm}^{3}\right)$ \\
\hline cubic foot per second $\left(\mathrm{ft}^{3} / \mathrm{s}\right)$ & Flow rate & \\
\hline
\end{tabular}

\section{Datum}

Vertical coordinate information is referenced to the North American Vertical Datum of 1988 (NAVD 88).

Horizontal coordinate information is referenced to the North American Datum of 1983 (NAD 83). Altitude, as used in this report, refers to distance above the vertical datum.

\section{Supplemental Information}

Concentrations of chemical constituents in water are given in milligrams per liter (mg/L). 


\section{Abbreviations}

$\begin{array}{ll}\text { BMI } & \text { Basic Magnesium Incorporated } \\ \text { EPA } & \text { U.S. Environmental Protection Agency } \\ \text { ET } & \text { Evapotranspiration } \\ \text { LVWCC } & \text { Las Vegas Wash Coordination Committee } \\ \text { NDEP } & \text { Nevada Department of Environmental Protection } \\ \text { NERT } & \text { Nevada Environmental Response Trust } \\ \text { SNWA } & \text { Southern Nevada Water Authority } \\ \text { TIMET } & \text { Titanium Metals Corporation } \\ \text { USGS } & \text { U.S. Geological Survey }\end{array}$




\title{
Discharge Data Collection and Analysis and Implications for Surface-Water/Groundwater Interactions in the lower Las Vegas Wash, Clark County, Nevada, 2016-18
}

\author{
By Jon W. Wilson
}

\section{Abstract}

The lower Las Vegas Wash represents the terminal surface drainage for the Las Vegas Valley in southern Nevada. In 1997, high concentrations of perchlorate were found in seeps contributing to discharge in this area and traced to an industrial byproduct from manufacturing operations in the mid-1900s at the nearby Basic Magnesium, Incorporated, plant. The discovery prompted a water-resources investigation by the Nevada Department of Environmental Protection (NDEP) to develop an understanding of the nearby groundwater flow system and the dynamics associated with surfacewater flow in the Wash. In 2016, the U.S. Geological Survey was tasked with evaluating surface-water discharge in the lower Las Vegas Wash near locations where perchlorate concentrations from the groundwater system had been detected. Results of this study will assist NDEP with identifying areas of groundwater and surface-water interaction and help guide future cleanup and monitoring efforts.

Streamflow discharge is evaluated along a 4-mile section of the lower Las Vegas Wash (referred to as the Wash) and used to describe surface-water and groundwater interactions between the Wash channel and bank sediments. Continuous discharge data were collected during a 2-year period (2016-18) at 5 gaging stations along the Wash. Additionally, multiple discrete measurements between gaging stations were collected during 4 synoptic sampling events between 2016 and 2018.

A diurnal discharge pattern, controlled by upstream treated wastewater releases, provided high- and low-discharge markers that are used to compute downstream time-lags of peak and minimum flows. Computed time-lags are used to establish travel times between measurement sites, and difference in upstream and time-lagged downstream hydrographs are used to compute increases (gain) or decreases (loss) in discharge between gaging stations or between gaging stations and discrete measurements. Tributary surface-water inflows to the lower Las Vegas Wash from wastewater discharge, remediation efforts, and periodic flooding from rainfall runoff are included in computing differences in discharge. Differences between discharge data from delineated reaches are used to define locations of daily, monthly, and yearly streamflow gains from or losses to adjacent bank sediments. Construction of additional channel-stabilization weirs have occurred since the completion of this study and the associated change to streamflow dynamics may limit study results to the period analyzed; however, methods and processes described in this report can be used in future evaluations.

\section{Introduction}

The lower Las Vegas Wash, Nevada, is north of Henderson and southeast of Las Vegas and extends approximately 12 miles from a U.S. Geological Survey (USGS) gaging station adjacent to and slightly (less than 2 miles) downstream of four wastewater discharge outlets (09419679; U.S. Geological Survey, 2018a), under Lake Las Vegas (through bypass tunnels), and to Las Vegas Bay at Lake Mead (fig. 1). Discharge from treated effluent, surface-water runoff from storm events, and subsurface drainge from the 2,193-square-mile $\left(\mathrm{mi}^{2}\right)$ drainage area in the Las Vegas Valley are the primary components that directly contributes to surface water at the lower Las Vegas Wash (Roline and Sartoris, 1997; Bureau of Reclamation, 1982). Baseflow discharge in lower Las Vegas Wash was intermittent until the mid-1960s, when flow increased because of population growth, resulting in increased urban runoff, treated wastewater, and industrial discharge.

The Basic Magnesium, Inc. (BMI), complex originally consisted of approximately 5,000 acres in Henderson, Nevada, to the south and adjacent to the lower Las Vegas Wash. The site was used for industrial-chemical production since at least 1942, and to produce magnesium for the U.S. Government during World War II. From 1950 through the 1960s, BMI changed ownership and manufactured perchlorate salts, mainly used as an oxidizing agent for rocket propellants. From the early 1940s through 1976, unlined evaporation ponds and ditches were used for the disposal of effluents from manufacturing (MWH, 2005). Perchlorate salts found in the effluent discharge infiltrated into the shallow groundwater and were 


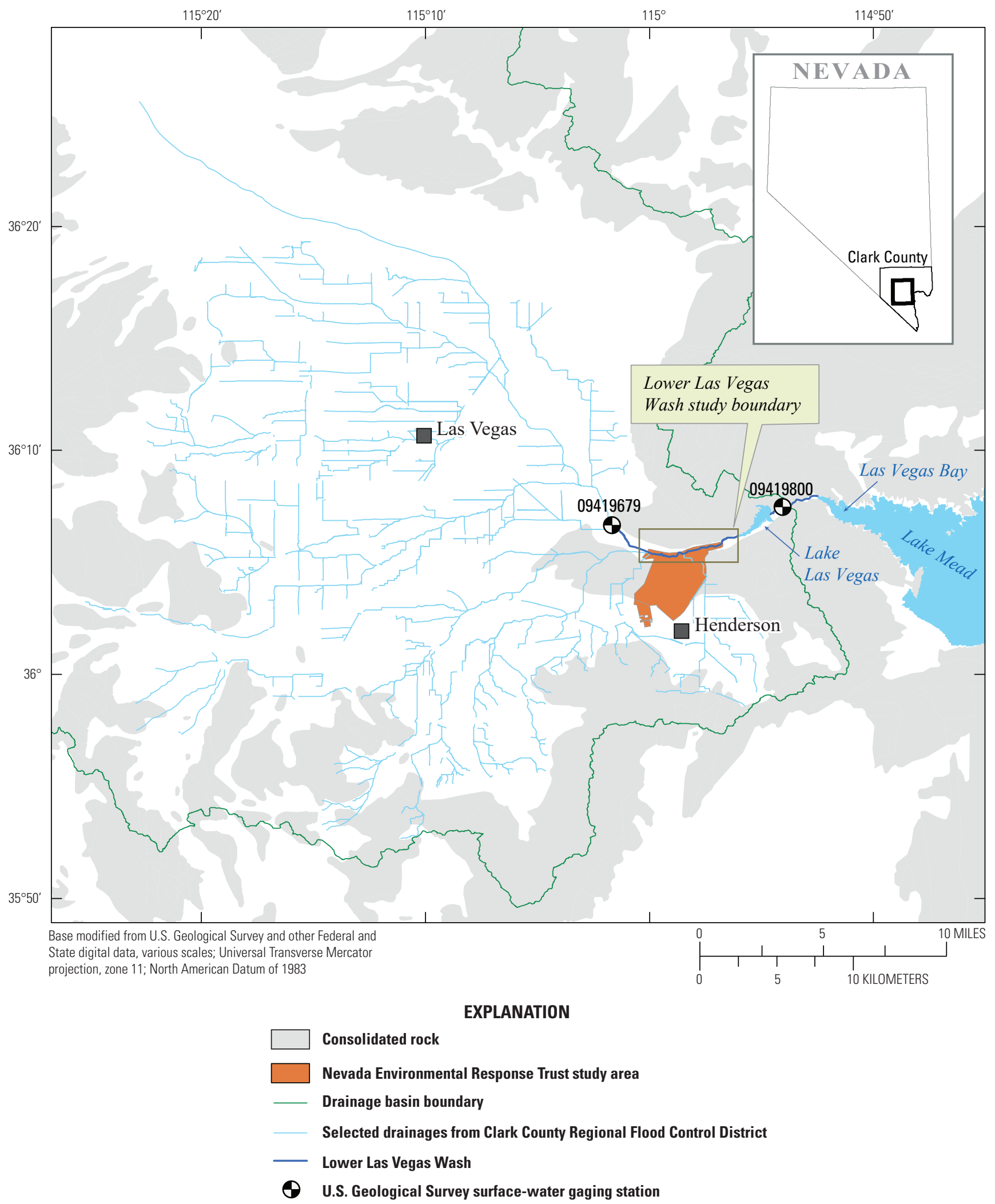

Figure 1. Location of Nevada Environmental Response Trust and lower Las Vegas Wash study areas in Clark County, Nevada. 
transported downgradient to the lower Las Vegas Wash and discovered in groundwater at the nearby BMI complex in 1997 (ENSR International, 2005).

The U.S. Geological Survey (USGS) has operated and maintained surface-water gaging stations along the lower Las Vegas Wash and has recorded discharge since 1957. These discharge records show an average annual increase in the total flow along the lower Las Vegas Wash from approximately 20 cubic feet per second $\left(\mathrm{ft}^{3} / \mathrm{s}\right)$ to over $300 \mathrm{ft}^{3} / \mathrm{s}$ from 1957 to 2017 (fig. 2). This increase in flow caused erosion that has widened and deepened the channel, exposed groundwater seeps along the banks, and has resulted in the transport of 224 million cubic feet $\left(\mathrm{ft}^{3}\right)$ of sediment downstream to Las Vegas Bay at Lake Mead (Whitney and others, 2015). Efforts to stabilize the channel and reduce erosion have been addressed by the construction of weirs made of concrete blocks and rock that bisect the lower Las Vegas Wash at varied intervals (fig. 3).

In 1999, a seep discharging approximately $0.9 \mathrm{ft}^{3} / \mathrm{s}$, on the right bank of lower Las Vegas Wash and upstream of the current Pabco Weir (U.S. Geological Survey, 2018b), was sampled and contained more than 100 milligrams per liter $(\mathrm{mg} / \mathrm{L})$ of perchlorate (ENSR International, 2005). This discovery prompted water-resources investigations, led by NDEP, to evaluate groundwater flow and the extent and transport of perchlorate in the area. Treatment of perchlorate in groundwater has been ongoing since 1999 to reduce concentrations reaching the lower Las Vegas Wash and ultimately Lake Mead, which is the primary source of municipal water for the Las Vegas Valley. Wildlife, plants, and soil associated with the lower Las Vegas Wash ecosystem have also been evaluated for perchlorate concentrations (Urbansky and others, 2000; Smith and others, 2004). In 2011, the U.S. Environmental Protection Agency (EPA) determined that perchlorate contamination may have an adverse effect on human health (U.S. Environmental Protection Agency, 2011), and perchlorate in drinking water systems became a public health concern. The Nevada Environmental Response Trust (NERT) was established in 2011 to investigate perchlorate contamination from the BMI complex, oversee hydrologic data collection, and evaluate transport and total quantities of perchlorate in proximity to the lower Las Vegas Wash (Nevada Environmental Response Trust, 2018). Additionally, NERT manages remediation facilities that remove perchlorate from the groundwater upgradient of the lower Las Vegas Wash and at the BMI complex. In 2012, analysis of perchlorate concentrations in groundwater identified perchlorate plumes ranging from more than $1,000 \mathrm{mg} / \mathrm{L}$ at the BMI complex to less than $1 \mathrm{mg} / \mathrm{L}$ at the lower Las Vegas Wash (ENSR International, 2005). In 2015, Endeavour, a limited liability company (LLC), was formed to continue remediation efforts at the NERT site.

In 2016, NDEP entered into a cooperative agreement with the USGS to assess surface-water flows along a segment of the lower Las Vegas Wash through the installation of three additional continuous surface-water gaging stations and semiannual synoptic discharge data collection at select locations. A spatial analysis of continuous and discrete discharge data for 2016-2018 were used to identify areas of groundwater and surface-water interaction and streamflow gains and losses along the lower Las Vegas Wash.

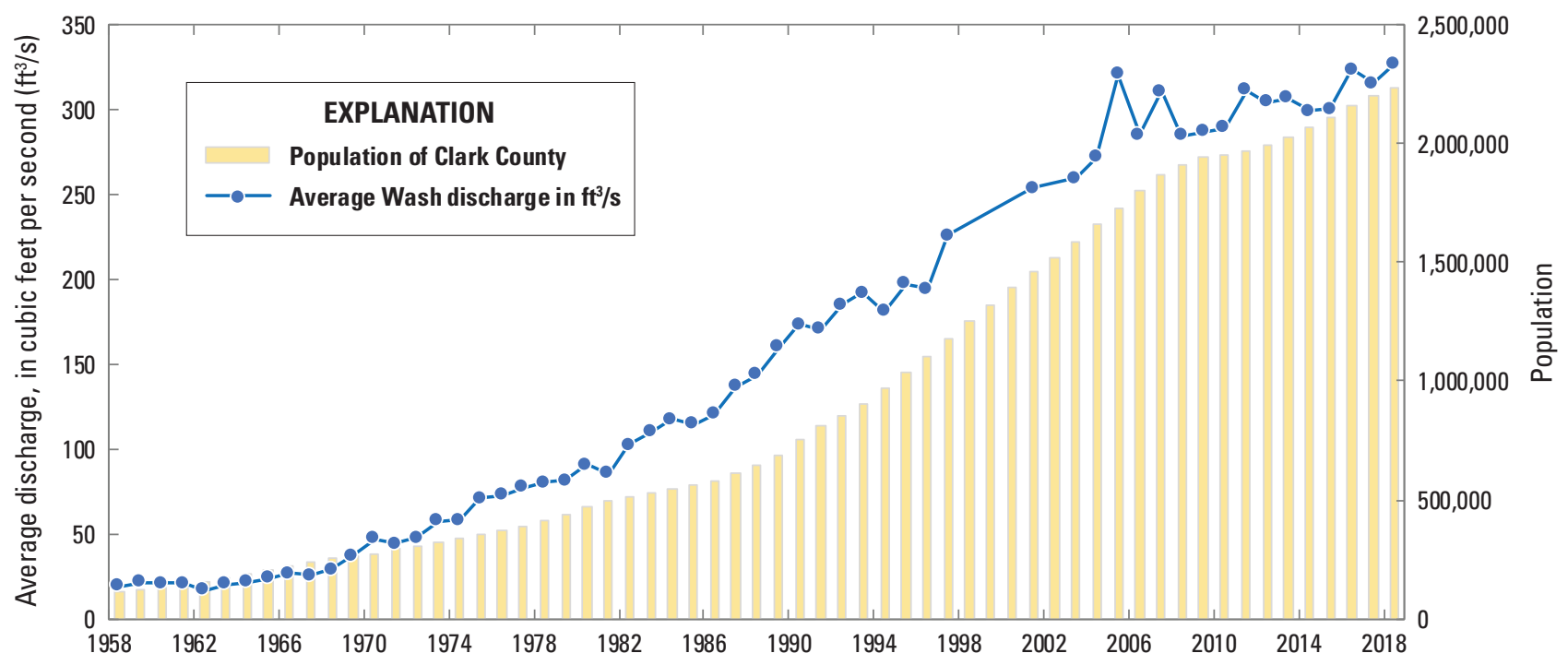

Figure 2. Population of Clark County and average annual discharge at the lower Las Vegas Wash, Clark County, Nevada, 1957 to 2017 (population data from U.S Census Bureau, 2020; discharge data from USGS National Water Information System [U.S. Geological Survey, 2018b, 2018c, and 2018d] for gaging stations 09419700, 09419753, and 09419800). 


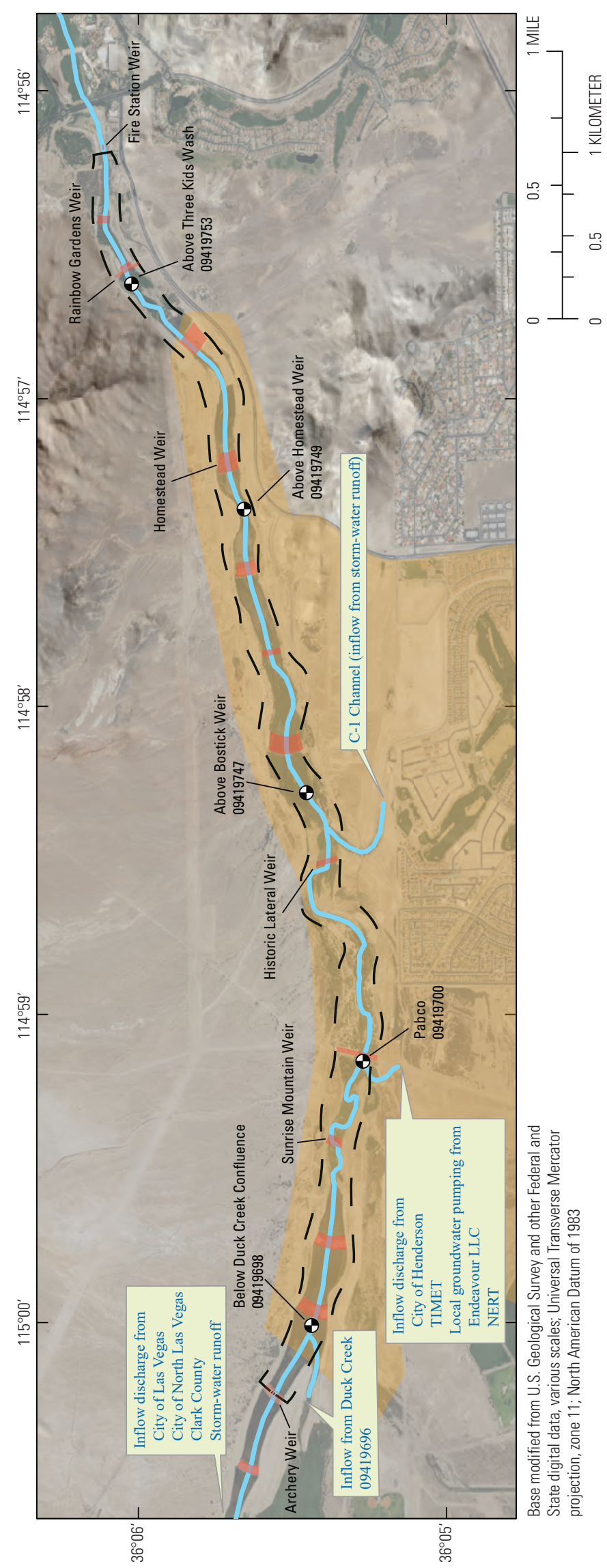

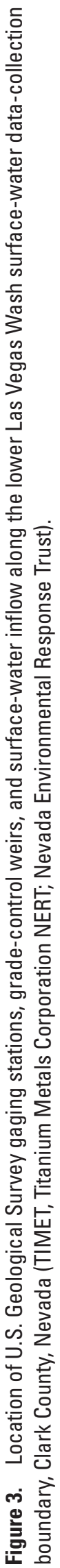




\section{Purpose and Scope}

This report presents the results of an evaluation of discharge data collected along the lower Las Vegas Wash, with the primary purpose of identifying areas of surface-water and groundwater interaction, and computing streamflow gains and losses. Disharge data from five continuous surface-water gages were collected along the lower Las Vegas Wash from Archery Weir downstream to Fire Station Weir to identify the temporal and spatial variations in gains and losses of discharge. Existing long-term continuous and discrete surface-water data provide information on the magnitude and timing of daily diurnal fluctuations and context for shorter-term (2016-2018) dynamics of the lower Las Vegas Wash. New data were collected in the lower Las Vegas Wash at continuous discharge stations and semiannual discrete measurements at multiple locations between 2016 and 2018 .

Data collected in the lower Las Vegas Wash since June 2018 were not interpreted because of channel changes resulting from construction activities that altered discharge transport times. For example, construction at the Sunrise Mountain Weir and Historic Lateral Weir changed the channel geometry by straightening meandering sections of the lower Las Vegas Wash, which subsequently altered travel times between surface-water gaging stations. Discharge is summarized for data collected prior to completion of these weir structures and a 2-year snapshop of discharge variation is presented for 2016-2018. Methods described in this report, however, can be used in future analyses to evaluate post-construction flow dynamics.

Groundwater water-level data provided by NERT (Nevada Environmental Response Trust, 2018) were used to support interpretations of groundwater and surface-water interactions through adjacent bank sediments. The altitude and timing between changes in surface-water stage and nearby groundwater levels are presented to support interpretations of streamflow gain or loss. Hydraulic processes that control the exchange between surface-water and groundwater were not analyzed and are outside the scope of this project.

\section{Description of Study Area}

The study area is a 4-mile reach of lower Las Vegas Wash (subsequently referred to as the Wash) between Archery Weir and Fire Station Weir (fig. 3). Discharge to the Wash includes treated effluent from wastewater treatment plants (operated by Clark County Water Reclamation District, City of Las Vegas, City of Henderson, and the City of North Las Vegas), urban and periodic storm-water runoff from the drainage basin, and groundwater discharge emanating from seeps along the Wash. Wastewater effluent-discharge is released in a diurnal cycle to the Wash. Discharge variation from effluent flow is characterized by increasing (gaining) discharge in late afternoon to early morning and decreasing (losing) discharge from morning to afternoon; a pattern that is common in streams fed by urban wastewater (Chesner and Pai, 1981). Discharge from Duck Creek (U.S. Geological Survey, 2018e), the only perennial tributary to the Wash, contributed a yearly average discharge of approximately $11 \mathrm{ft}^{3} / \mathrm{s}$ from 2016 to 2018 . The largest ephemeral contributions to the Wash are periodic storm-water runoff from heavy rainfall events that occur as flash floods typically lasting less than a few hours.

The Las Vegas Wash Coordination Committee (LVWCC) and Southern Nevada Water Authority (SNWA) manage and promote improvement of the lower Las Vegas Wash that includes channel stabilization, ecosystem development, and sustainability. More than 500 acres of native riparian and upland habitats border the lower Las Vegas Wash channel (Las Vegas Wash Coordination Committee, 2018). As of June 2017, the LVWCC and SNWA completed the construction of 14 grade-control weirs (Southern Nevada Water Authority, 2018b). These concrete blocks and rock structures stabilize bank and channel sediments, slow flow velocities, create additional wetland habitat, and reduce erosion from periodic flooding. For example, weir structures slow surface-water velocities and create shallow and wide sections at base flow between USGS gaging stations Below Duck Creek Confluence and Pabco (fig. 3), deepen incised channels between Pabco and Above Bostick Weir, and create shallow and wide sections between Above Bostick Weir and Above Three Kids Wash. In addition to the effect of weirs, the change in channel sinuosity throughout the lower Las Vegas Wash contribute to slower water velocities.

Downgradient of the BMI complex, groundwater containing perchlorate is monitored and remediated in by NERT, TIMET, and Endeavor. Groundwater is extracted for ex-situ treatment, perchlorate concentrations are reduced, and water is returned to the Wash upstream of the Pabco gaging station (fig. 3). Return flows of water treated for perchlorate are commonly less than $10 \mathrm{ft}^{3} / \mathrm{s}$ (Nevada Environmental Response Trust, 2018). Additional activities in the NERT study site include monitoring well installation, water-level data collection, estimation of hydraulic properities from aquifer testing, hydrogeologic interpretation, and groundwater modeling.

\section{Previous Work}

Federal guidelines set by the Colorado River Compact of 1922 and Boulder Canyon Project Act of 1928 provide a framework for SNWA to manage more than 300,000 acre-feet of water allotted to southern Nevada. These Federal authorizations state that treated water from Las Vegas Valley that flows into Lake Mead via the Las Vegas Wash is considered "return flow" and is credited to the area's available water resource. Rapid population growth in the Las Vegas Valley has resulted in increased water use and return flow that has become a portion of the water managed by SNWA (Southern Nevada Water Authority, 2018b). Increased return flow from wastewater effluent and stormwater runoff has altered the fluvial 
morphology in the Wash through degradation and erosion of the floodplain (Whitney and others, 2015). Efforts to counteract continued erosion, as previously described, include the construction of concrete blocks and rock-grade control weirs in the channel.

Increasing discharge, downcutting, and construction have altered the geomorphology, flow dynamics, and water quality of the lower Las Vegas Wash. Hydrologic data collected by SNWA and USGS documents the associated changes to streamflow and water quality (Southern Nevada Water Authority, 2018a; U.S. Geological Survey, 2018). The physical discharge and chemical composition of the Wash are summarized in hydrologic reports that focus on total return flow to Lake Mead (Southern Nevada Water Authority, 2018b), bed-load transport and channel erosion (Duan and Scott, 2007; Whitney and others, 2015), and water quality trends (Morris and Paulson, 1983; Roline and Sartoris, 1984; Las Vegas Wash Coordination Committee, 2018).

From late 2014 through 2018, NERT managed multiple groundwater and surface-water sampling efforts and environmental investigations that provide insight into groundwater dynamics near the lower Las Vegas Wash (Nevada Environmental Response Trust, 2018). These efforts, referred to as the Remedial Investigation Study, focus on the groundwater flow system in the NERT study area adjacent to the lower Las Vegas Wash and to the south toward the BMI complex (fig. 3). The Remedial Investigation Study collected soil and groundwater samples for chemical analysis and created a local-scale groundwater flow model used to guide sampling and contaminant remediation efforts. These efforts identify the extent of environmental impacts to the lower Las Vegas Wash and help identify remedial actions that will reduce risks to human health and the environment.

\section{Methods}

Discharge measurements made along a segment of the Wash, between gaging stations, is termed a "reach" and used in this report to describe changes in streamflow. A reach between continuous discharge gaging stations are referred to as Reach No. 1, 2, 3, and 4, and a subreach between discrete measurement sites and gaging stations are identified as R-1 through R-11 (fig. 4). Reach distances were derived from an updated georeferenced trace of the Wash thalweg, which is published separately as a USGS data release (Wilson, 2021).

Locations of streamflow gain and loss along the Wash are identified using discharge differences in continuous measurements at gaging stations for each reach, and differences in continuous and discrete measurements above or below gaging stations for each subreach (fig. 5). Hydrographs of continuous and repeated discrete discharge measurements were corrected for time-lag by matching daily maximum or minimum discharge periods between measurement sites (table 1). Differences in the time of the daily minimum or maximum discharge and measured distance between upstream and downstream gaging stations were used to establish travel times. For example, the difference between the observed maximum or minimum discharge at the Pabco gaging station and the observed maximum or minimum discharge at Above Three Kids Wash station is 1 hour and 45 minutes (fig. 5). Travel times for subreaches were rounded to the nearest 15-minute value to more easily compare to travel times derived for reaches using continuous records (fig. 6). The discharge at time-lagged hydrographs for downstream measurement sites were then directly compared to the discharge at uncorrected upstream hydrographs to compute gain or loss at equivalent streamflow conditions. Downstream discharge values are subtracted from upstream values and differences are reported as change in discharge. Additional inflow that enters the Wash upstream of Pabco, was adjusted for time-lag and added to discharge from Below Duck Creek Confluence. Inflow upstream of Bostick Weir, from C-1 Channel, is not included in the analysis because yearly average discharge from this site is less than $1 \mathrm{ft}^{3} / \mathrm{s}$ and not considered significant.

A total of 135 discrete discharge measurements were made at 7 sites during 4-day-long (8 a.m. to 4 p.m.) synoptic data-collection events in December 2016, June 2017, December 2018, and June 2018. Discrete measurements were time-adjusted to the nearest 15-minute interval, and linearly interpolated between measurements to produce a theoretical discharge hydrograph that was compared to hydrographs from continuous stream gages (fig. 6). Nine measurements were excluded from hydrographic comparison because of lack of data necessary to curve match to continuous record with certainty. Hydrographs from continuous stream gages were then compared to the interpolated hydrographs compiled from discrete measurements to compute differences in discharge and gain or loss for subreaches.

Groundwater levels from observation wells near the Wash were used to evaluate change in water levels in relation to changing stream stage. The proximity of the longitudinal groundwater profile and stream stage also was graphical compared. The degree of hydraulic connection and time-lag between diurnal changes in stream stage at gaging stations and the corresponding response of water levels in wells is approximated by visual comparison of stage and water-level hydrographs.

Computed change in discharge between measurement sites along the Wash can be attributed to either groundwater inflow/outflow or an exchange of water in the hyporheic zone through bank sediments; however, differentiating between these sources is beyond the scope of this study. Thus, the hydraulic mechanism of water exchange between the open channel and saturated subsurface are referred to as originating from bank sediments. Moreover, discharge gain and loss within a reach and subreach are described and referred to as differences in discharge without reference to the actual process causing increased (gaining) or decreased (losing) discharge between gaging stations and discrete measurement sites. 


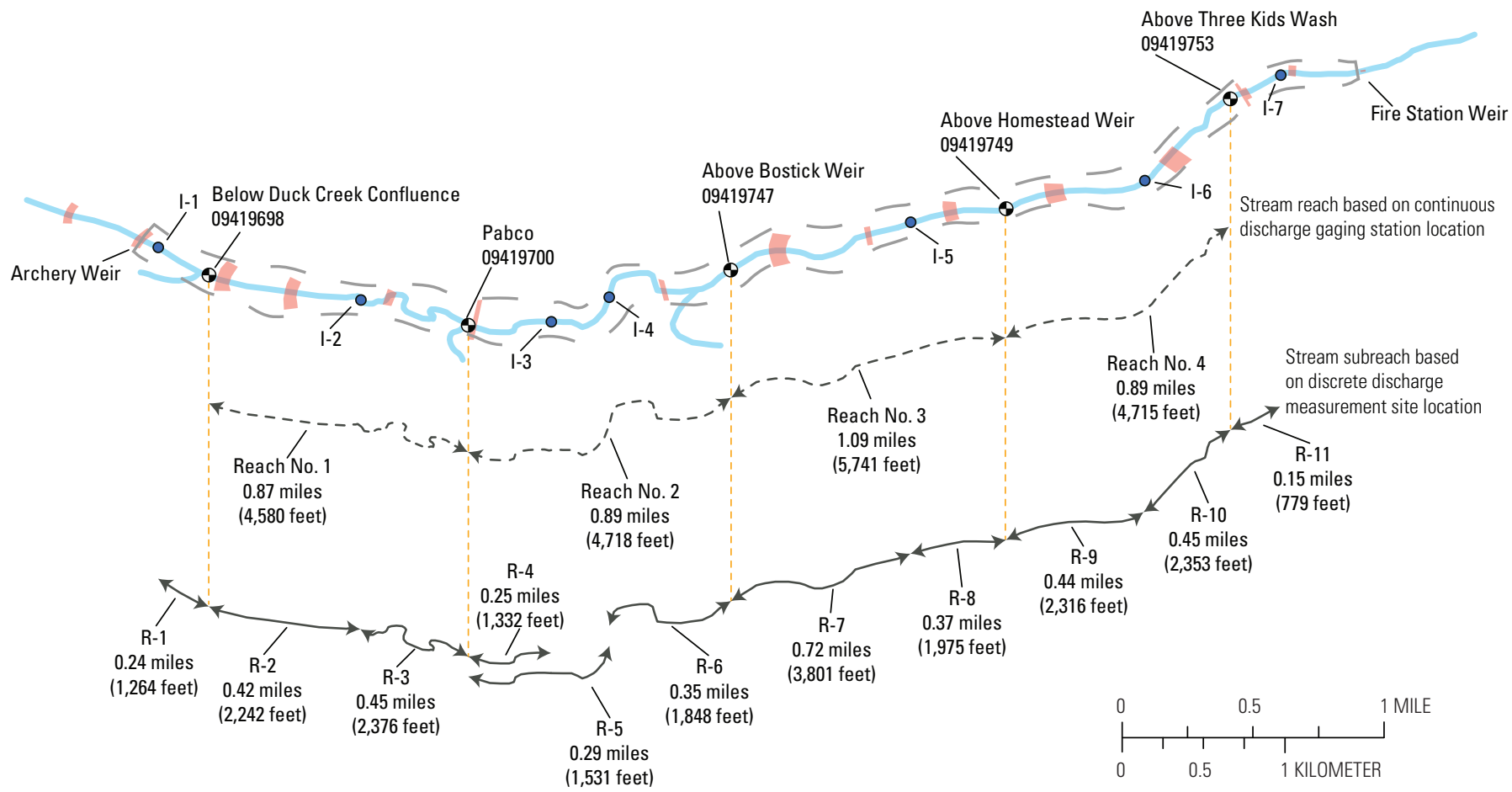

EXPLANATION

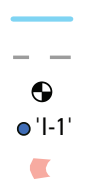

Lower Las Vegas Wash and tributary inflow
Surface-water data-collection boundary
U.S. Geological Survey surface-water gaging station
Discrete surface-water measurement site
Channel stabilization weir

Distance between measurement sites in river miles

$\longleftrightarrow-$ Reach No. 1 Reach distance in river miles

$\longleftrightarrow$ R-1 Subreach distance in river miles

Channel stabilization weir

Figure 4. Discharge gaging station and discrete measurement site locations and distances between measurement sites along the lower Las Vegas Wash and tributary inflow, Clark County, Nevada.

\section{Discharge Data Collection}

The USGS historically and currently (2021) monitors surface-water discharge at gaging stations at Pabco and Above Three Kids Wash. Between these stations, grade-control weirs reduce flow velocity, while inflow from seeps and flood flow at C-1 Channel (fig. 3) contributes to total discharge. Additional continuous-record gaging stations were needed to refine an understanding of the spatial patterns of gains and losses along the Wash. Thus, in August 2016, three additional surface-water gaging stations were installed and began operation using USGS field techniques and protocol (Turnipseed and Sauer, 2010). Continuous discharge records were computed following standard USGS techniques (Wahl and others, 1995), and complete discharge records were compiled for all five gaging stations for the period between August 2016 through June 2018. Minimal estimated record and no data gaps or uninterpreted anomalies caused by data loss were noted for the period-of-record analyzed. Short-duration flood flows are included in the annual, seasonal, and monthly total discharge values for this period because these short-duration flows do not significantly change the long-term average value for streamflow.

Discrete discharge measurements were made at seven additional locations (table 2) on December 8, 2016; June 8 and December 6, 2017; and June 6, 2018 (table 3). These synoptic data-collection events reflect periods during winter (December) and summer (June) months of low and high evapotranspiration (ET), respectively. Timing of discrete streamflow measurements was selected to evaluate the effect of changing ET and associated riparian vegetation water consumption on discharge. Discrete measurement sites were selected between gaging stations, and at stream locations that conform to USGS measurement standards. For example, discrete measurements were made above bends in the stream channel, at wide shallow sections, and upstream of tributary inflows. Measurement sites were added and removed between synoptic measurement collection events in response to field conditions that included accessibility issues caused by construction and conditions in the channel that did not fully meet USGS field data-collection requirements. Discrete 
Table 1. Average lag in streamflow travel time between U.S. Geological Survey gaging stations and discrete measurement sites along the lower Las Vegas Wash, Clark County, Nevada. Discrete and continuous discharge measurement locations are shown on figure 4.

[h:mm, hour:minutes; No., number]

\begin{tabular}{|c|c|c|c|c|c|}
\hline $\begin{array}{l}\text { Reach or sub- } \\
\text { reach }\end{array}$ & From & To & $\begin{array}{c}\text { Time-lag } \\
\text { (h:mm) }\end{array}$ & $\begin{array}{c}\text { Cumulative time- } \\
\text { lag (h:mm) }\end{array}$ & $\begin{array}{c}\text { Distance } \\
\text { (feet) }\end{array}$ \\
\hline \multicolumn{6}{|c|}{ Continuous gaging stations } \\
\hline Reach No. 2 & Pabco & Above Bostick Weir & $0: 15$ & $1: 15$ & 4,718 \\
\hline Reach No. 3 & Above Bostick Weir & Above Homestead Weir & $0: 45$ & 2:00 & 5,741 \\
\hline R-1 & $\mathrm{I}-1$ & Below Duck Creek Confluence & $0: 30$ & $0: 30$ & 1,264 \\
\hline $\mathrm{R}-2$ & Below Duck Creek Confluence & $\mathrm{I}-2$ & $0: 15$ & $0: 45$ & 2,242 \\
\hline $\mathrm{R}-3$ & $\mathrm{I}-2$ & Pabco & $0: 15$ & $1: 00$ & 2,376 \\
\hline $\mathrm{R}-4$ & Pabco & $\mathrm{I}-3$ & $<0: 15$ & $1: 00$ & 1,332 \\
\hline $\mathrm{R}-8$ & $\mathrm{I}-5$ & Above Homestead Weir & $0: 15$ & 2:00 & 1,975 \\
\hline R-9 & Above Homestead Weir & $\mathrm{I}-6$ & $0: 15$ & $2: 15$ & 2,316 \\
\hline $\mathrm{R}-10$ & I-6 & Above Three Kids Wash & $0: 30$ & $2: 45$ & 2,343 \\
\hline $\mathrm{R}-11$ & Above Three Kids Wash & $\mathrm{I}-7$ & $0: 15$ & $3: 00$ & 778 \\
\hline
\end{tabular}

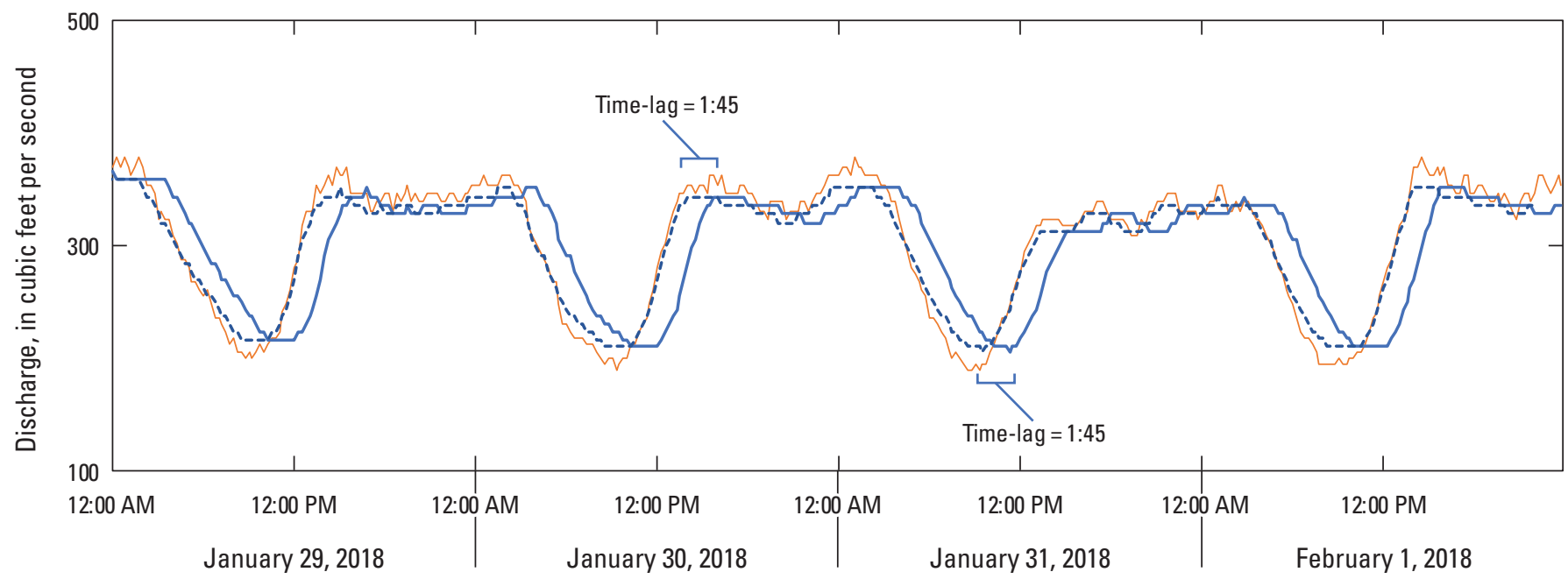

EXPLANATION

_ Pabco $09419700 \quad$ Above Three Kids Wash 09419753

Above Three Kids Wash (time-lag) 09419753

Figure 5. Comparison of discharge records for Pabco (U.S. Geological Survey, 2018b) and Above Three Kids Wash (U.S. Geological Survey, 2018c) stream gages showing the average time-lag between peak and minimum flows, lower Las Vegas Wash, Clark County, Nevada. Time-lagged hydrographs are shown as hours:minutes. 


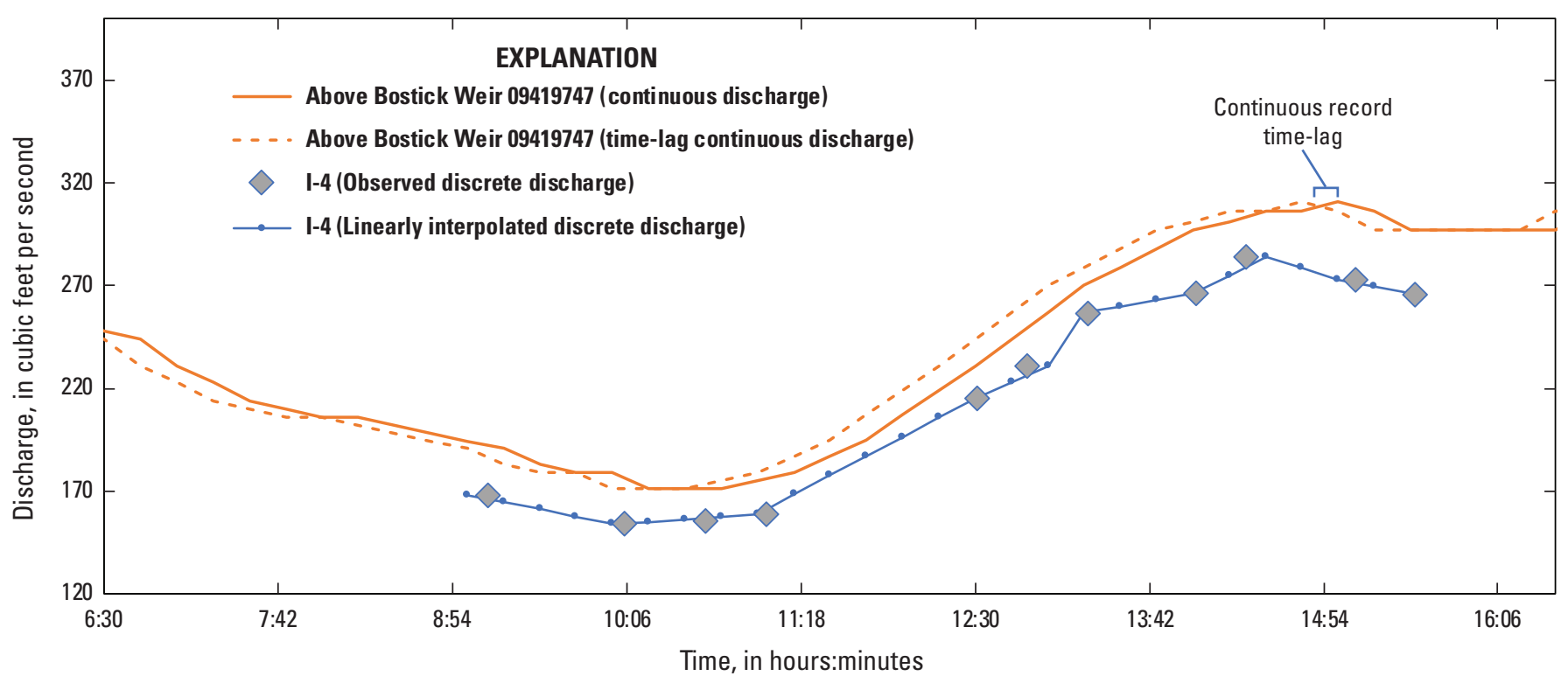

Figure 6. Comparision of interpolated discrete hydrograph and time-adjusted continuous discharge hydrograph from Above Bostick Weir (U.S. Geological Survey, 2018f), measured on June 8, 2017, lower Las Vegas Wash, Clark County, Nevada.

measurements were made with acoustic Doppler velocity meters (ADV) or acoustic Doppler current meter profilers (ADCP), using velocity-area methods described in Turnipseed and Sauer (2010) and Mueller and others (2013) and are consistent with methods described by the American Society for Testing and Materials standards (American Society for Testing and Materials, 2013). All measurements are publicly available and can be accessed through the USGS NWISWeb portal (U.S. Geological Survey, 2018).
Data for additional surface-water (effluent) inflow from wastewater treatment, tributary inflow from off-stream pump-and-treat systems that contribute flow in the Wash, and groundwater levels were compiled and provided by NERT. Surface-water discharge summaries include tributary inflow from City of Henderson wastewater treatment, tributary inflow from TIMET, local groundwater pumping, and treatment from NERT and Endeavour remediation activities (table 4; fig. 3). Discharge from these sources are delivered to the

Table 2. Summary of gaging stations and discrete measurement locations along the lower Las Vegas Wash, Clark County, Nevada.

[USGS, U.S. Geological Survey; ID, identification; DMS, degrees minutes seconds]

\begin{tabular}{|c|c|c|c|c|c|}
\hline USGS site ID & Site name & Data frequency & Latitude (DMS) & $\begin{array}{c}\text { Longitude } \\
\text { (DMS) }\end{array}$ & Period of record \\
\hline 09419698 & Below Duck Creek Confluence & Continuous & $36^{\circ} 05^{\prime} 30^{\prime \prime}$ & $114^{\circ} 59^{\prime} 57^{\prime \prime}$ & 2016-Present \\
\hline 09419747 & Above Bostick Weir & Continuous & $36^{\circ} 05^{\prime} 23^{\prime \prime}$ & $114^{\circ} 58^{\prime} 20^{\prime \prime}$ & 2016-Present \\
\hline 09419749 & Above Homestead Weir & Continuous & $36^{\circ} 05^{\prime} 39^{\prime \prime}$ & $114^{\circ} 57^{\prime} 18^{\prime \prime}$ & 2016-Present \\
\hline 360533115001101 & Below Archery Weir & Discrete & $36^{\circ} 05^{\prime} 33^{\prime \prime}$ & $115^{\circ} 00^{\prime} 11^{\prime \prime}$ & $2016-18$ \\
\hline 360521114592701 & Sunrise Mountain & Discrete & $36^{\circ} 05^{\prime} 22^{\prime \prime}$ & $114^{\circ} 59^{\prime} 31^{\prime \prime}$ & 2016-18 \\
\hline 360517114585301 & Middle Way & Discrete & $36^{\circ} 05^{\prime} 17^{\prime \prime}$ & $114^{\circ} 58^{\prime} 53^{\prime \prime}$ & $2016-18$ \\
\hline 360524114584001 & Below Middle Way & Discrete & $36^{\circ} 05^{\prime} 24^{\prime \prime}$ & $114^{\circ} 58^{\prime} 41^{\prime \prime}$ & $2016-18$ \\
\hline 360606114562002 & Above Powerline Crossing & Discrete & $36^{\circ} 06^{\prime} 06^{\prime \prime}$ & $114^{\circ} 56^{\prime} 28^{\prime \prime}$ & $2016-18$ \\
\hline
\end{tabular}


Table 3. Summary of the number of discrete discharge measurements made during synoptic data-collection events along the lower Las Vegas Wash, Clark County, Nevada.

[USGS, U.S. Geological Survey; ID, identification; *, not used for hydrograph comparison; - , no data]

\begin{tabular}{|c|c|c|c|c|c|c|}
\hline \multirow[b]{2}{*}{ Subreach } & \multirow[b]{2}{*}{ USGS site ID } & \multirow[b]{2}{*}{ Site name } & \multicolumn{4}{|c|}{ Number of measurements } \\
\hline & & & $\begin{array}{c}\text { December 8, } \\
2016\end{array}$ & June 8, 2017 & $\begin{array}{c}\text { December 6, } \\
2017\end{array}$ & June 6, 2018 \\
\hline $\mathrm{I}-2$ & 360521114592701 & Sunrise Mountain & $2 *$ & 6 & \multicolumn{2}{|c|}{$\begin{array}{l}\text { Restricted owing to con- } \\
\text { struction }\end{array}$} \\
\hline $\mathrm{I}-5$ & 360535114574001 & Lower Narrow & $2 *$ & 13 & $3 *$ & $2 *$ \\
\hline $\mathrm{I}-6$ & 360549114564801 & Above Three Kids Weir & - & 8 & 8 & 7 \\
\hline $\mathrm{I}-7$ & 360606114562002 & Above Powerline Crossing & - & 7 & 5 & 7 \\
\hline
\end{tabular}

Wash through a concrete culvert upstream and tributary to the gaging station at Pabco. These data were organized, averaged (when oversampled), and reduced to a 15-minute interval using SeriesSEE, a USGS Microsoft $\AA$ Excel add-in (Halford and others, 2012) to match the data frequency of time-series discharge data for continuous gaging stations. Surface-water inflows were added to the Below Duck Creek Confluence discharge record for comparison to time-lag downstream gages. The Below Duck Creek Confluence gage (U.S. Geological Survey, 2018g) is the only gage upstream of the point where tributary inflows reach the Wash.

\section{Discharge Accuracy}

Reported accuracy of continuous discharge records at USGS surface-water gaging stations depends on several factors that require a qualitative assessment of individual discrete measurements and general assessment of continuous record (Kennedy, 1983; Turnipseed and Sauer, 2010). For this study, gaging stations were visited every 4 to 6 weeks to collect discrete discharge measurements that provide greater accuracy and validation of continuous discharge records. Accuracy of individual discrete discharge measurements made during gaging stations visits and during synoptic data-collection events are affected by channel geometry and composition, spacing of observation verticals, and the stability of streamflow velocity and stage (Rantz, 1982; Turnipseed and Sauer, 2010). These observations provide a basis for rating individual measurements as poor, fair, good, or excellent (described as within more than $8,8,5$, or 2 percent of true values, respectively). Continuous streamflow records are assigned a qualifier of excellent, good, fair, or poor based on streambed and discrete measurement conditions during site visits. These qualifiers are described as 95 percent of reported daily discharge to be within $5,10,15$, or greater than 15 percent of true values (Rantz, 1982; Turnipseed and Sauer, 2010). During the study period, the continuous streamflow record measured at Above Homestead Weir (U.S. Geologial Survey, 2018h) was rated fair (uncertainty of \pm 15 percent), and the remaining four gages within the study area were rated poor (uncertainty of more than \pm 15 percent).

Although the reported accuracy for discrete and continuous discharge records is poor to fair, the relative measurement uncertainty is reduced by summing discharges over months and years. Uncertainty in continuous discharge records can be extremely complex (Kennard and others, 2010), but relatively small differences in cumulative measured discharge over months and years are often interpreted as meaningful (Lizárraga and Wehmeyer, 2012; Capesius and Arnold, 2012). For the Wash, small differences in measured cumulative discharge based on 3-years of data from five continuous gaging stations are considered to reduce the uncertainty of poor to fair discharge records. 
Table 4. Summary of discharge from tributary inflows to lower Las Vegas Wash above U.S. Geological Survey gage at Pabco (09419700), and sources of data for treated groundwater and wastewater, lower Las Vegas Wash, Clark County, Nevada.

[Source: https://www.nert-trust.com/. Abbrevations: $\mathrm{ft}^{3}$ /s, cubic feet per second; TIMET, Titanium Metals Corporation; NERT, Nevada Environmental Response Trust]

\begin{tabular}{|c|c|c|c|c|c|}
\hline \multirow{3}{*}{ Date } & \multicolumn{5}{|c|}{ Discharge $\left(\mathrm{ft}^{3} / \mathrm{s}\right)$} \\
\hline & \multicolumn{3}{|c|}{ Source of treated groundwater data } & \multirow{2}{*}{$\begin{array}{c}\text { Treated wastewater data } \\
\text { City of Henderson }\end{array}$} & \multirow{2}{*}{ Total inflow } \\
\hline & TIMET & NERT & Endeavour & & \\
\hline Dec. 2016 & 3.98 & 2.06 & 1.65 & 27.5 & 35.06 \\
\hline Jan. 2017 & 3.82 & 2.12 & 1.64 & 28.71 & 36.21 \\
\hline Feb. 2017 & 3.78 & 2.27 & 1.42 & 28.51 & 35.83 \\
\hline Mar. 2017 & 4.18 & 2.69 & 1.61 & 25.09 & 33.33 \\
\hline Apr. 2017 & 3.85 & 2.8 & 1.71 & 22.12 & 29.98 \\
\hline May 2017 & 4.75 & 2.81 & 1.67 & 18.64 & 27.87 \\
\hline June 2017 & 5.35 & 2.46 & 1.72 & 15.98 & 25.02 \\
\hline Jul. 2017 & 6.34 & 2.64 & 1.71 & 18.35 & 28.56 \\
\hline Aug. 2017 & 5.92 & 2.66 & 1.71 & 20.35 & 30.56 \\
\hline Sep. 2017 & 6.51 & 3.11 & 1.69 & 20.2 & 31.5 \\
\hline Oct. 2017 & 4.81 & 3.04 & 1.69 & 21.3 & 30.78 \\
\hline Nov. 2017 & 4.25 & 2.75 & 1.7 & 23.29 & 32 \\
\hline Dec. 2017 & 4.62 & 2.7 & 1.71 & 26.88 & 35.66 \\
\hline Jan. 2018 & 4.34 & 2.78 & 1.71 & 27.16 & 35.85 \\
\hline Feb. 2018 & 4.44 & 2.8 & 1.7 & 27.21 & 36.09 \\
\hline Mar. 2018 & 5.27 & 2.8 & 1.7 & 27.26 & 36.99 \\
\hline Apr. 2018 & 4.52 & 2.71 & 1.69 & 24.06 & 32.74 \\
\hline May 2018 & 5.03 & 2.75 & 1.66 & 23.58 & 32.98 \\
\hline June 2018 & 8.38 & 2.86 & 1.67 & 21.14 & 34.05 \\
\hline
\end{tabular}

\section{Discharge Analysis}

Discrete and continuous discharge measurements in the Wash are used to describe gain and loss of flow. Discharge measurements are evaluated over the entire period of record using datasets for selected gaging stations, and over the study period between 2016 and 2018. Long-term discharge differences at each reach provide a general trend of gain and loss and context for understanding shorter periods of discharge record. For example, subtracting the average monthly discharge at the downstream Above Three Kids Wash gaging stationfrom the upstream Pabco gaging station for $2005-2018$ results in mostly periods of positive difference and associated streamflow gain from bank sediments (fig. 7). However, discharge differences between these two gages from late 2016 through 2018 are consistently negative. Shorter-term negative discharge differences can be attributed to slower discharge velocities causing backwater seepage into bank sediments above channel stabilization weirs.

\section{Water Year 2017 and 2018 Discharge Variation}

Yearly average flows at each of the five gages along the Wash (fig. 8) are similar in water years 2017 and 2018 (from October 1, 2016, to September 30, 2018). However, differences between discharge records during this period suggest that Reaches No. 1 and No. 3 are gaining flow and Reaches No. 2 and No. 4 are losing flow. Differences in yearly average flow between gages are within 15 percent and within the margin of error of individual surface-water records. Additionally, a near-monotonic trend in cumulative gains and losses, computed from average monthly discharge (fig. 9), indicates that differences in discharge are consistently increasing (gaining) in Reaches No. 1 and No. 3 and consistently decreasing (losing) in Reaches No. 2 and No. 4. For the 21-month study period (August 2016 to June 2018), Reaches No. 1 and No. 3 are gaining 19 and 18 months, respectively; and Reaches No. 2 and No. 4 are losing 18 months each (fig. 10). The relatively high frequency at which positive or negative monthly discharge differences occur indicates that discharge gain at Reaches No. 1 and No. 3 and loss at Reaches No. 2 and No. 4 likley occur even though the magnitude of most monthly 


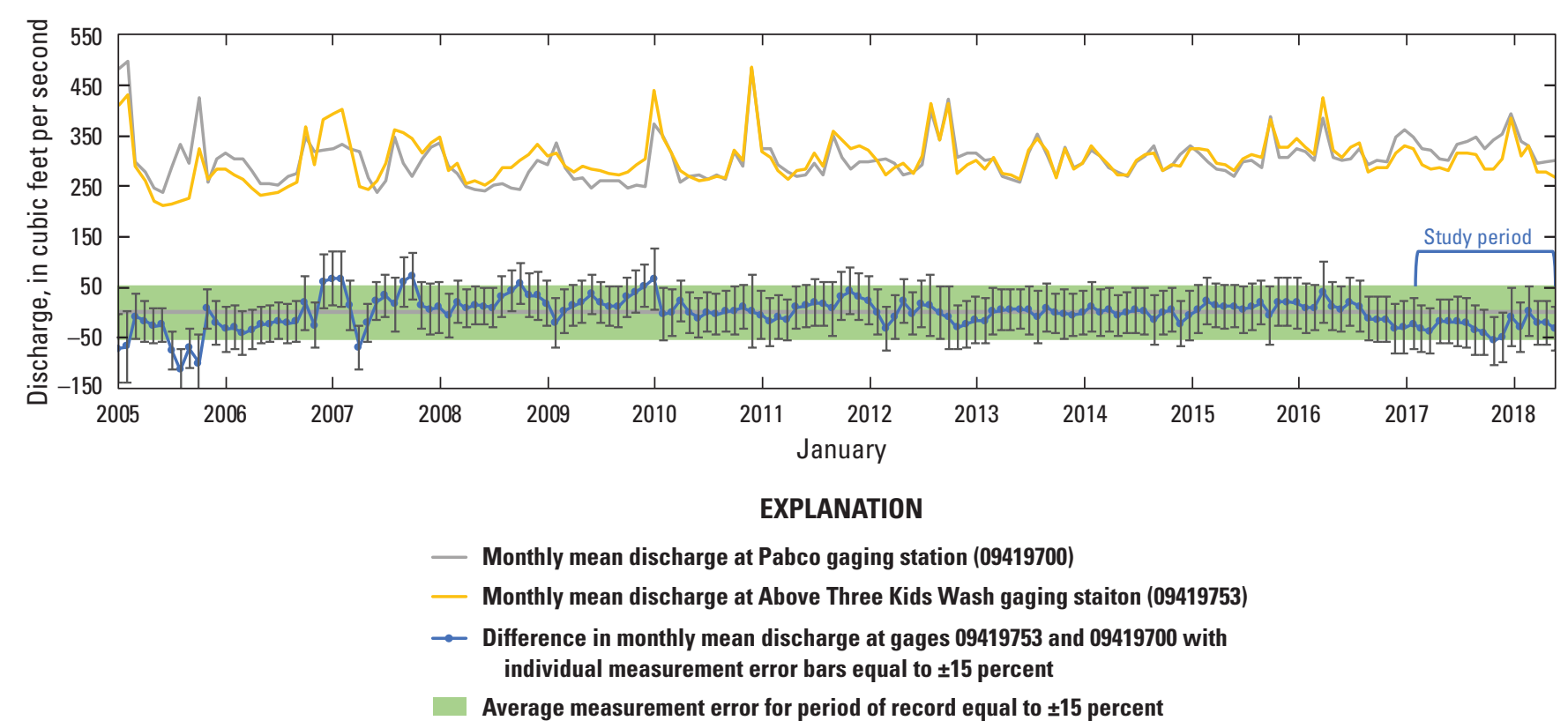

Figure 7. Monthly mean discharge at Pabco and Above Three Kids Wash gaging stations (U.S. Geological Survey, 2018b, 2018c) from January 2005 to June 2018. Difference computed by subtracting the monthly mean discharge for Above Three Kids Wash gaging station from the montly mean discharge for Pabco gaging station, lower Las Vegas Wash, Clark County, Nevada.

differences are within measurement error because, as stated previously, the relative measurement uncertainty is reduced by summing discharges over months and years.

\section{Seasonal Discharge Variations}

Discharge data for the Wash were averaged to 3-month periods to evaluate seasonal changes in streamflow. Although Las Vegas Valley receives periodic snowmelt-generated recharge to the groundwater system from the surrounding Spring Mountains and Sheep Range, seasonal effects on the Wash discharge from this water source are likely masked by more local and dominant influences on discharge such as evapotranspiration (ET), increased municipal water use during spring and summer, and winter and summer rainstorms. These factors cause discharge in the Wash to be highest in winter and summer months, and lowest in spring and fall months (fig. 11). Effects of ET from riparian vegetation along the Wash on the average seasonal discharge are low during the winter months and increase in the spring, resulting in higher and lower average discharge, respectively. Increased Wash discharge from spring to summer months primarily is caused by increased groundwater use and return flow from (1) residential landscapes, subsequent infiltration to the shallow aquifer, and return flows to the Wash and (2) increased municipal pumping and associated treated effluent discharge to the Wash (Harlan and others, 2009).

\section{Daily Discharge Variations Between Gaging Stations}

Daily streamflow flucutations in the Wash are primarily caused by variations in upstream wastewater discharges. Higher flows occur in the early evening to early morning hours, and lower flows occur in the late morning to midafternoon hours. Streamflow is further controlled by bank stabilization weirs that contribute to the downstream interaction with bank sediments and reaches that gain or lose flow. Weirs slow streamflow velocities and back-up water providing longer streamflow residence time and higher water stage. Discharge measured between gaging stations are affected by multiple bank stabilization weirs and channel morphology. Change in flow from weirs and channel sinuosity affect the magnitude of gain or loss in streamflow within a reach computed as a difference in daily discharge between gaging stations (downstream discharge minus upstream discharge).

Differences in daily discharge (fig. 12) indicate that most reaches are consistently gaining inflow from bank sediments to the Wash (positive discharge difference) or consistently losing streamflow from the Wash to bank sediments (negative discharge difference). Positve and negative discharge differences appear above and below the zero discharge difference line, respectively (fig. 12). The zero discharge difference line represents a point in time when stream stage equals the altitude of the water table in bank sediments. As stream discharge and stage decrease, water levels in the bank sediments become higher than the stream stage and groundwater begins to seep into the channel. Conversely, as stream discharge and stage 


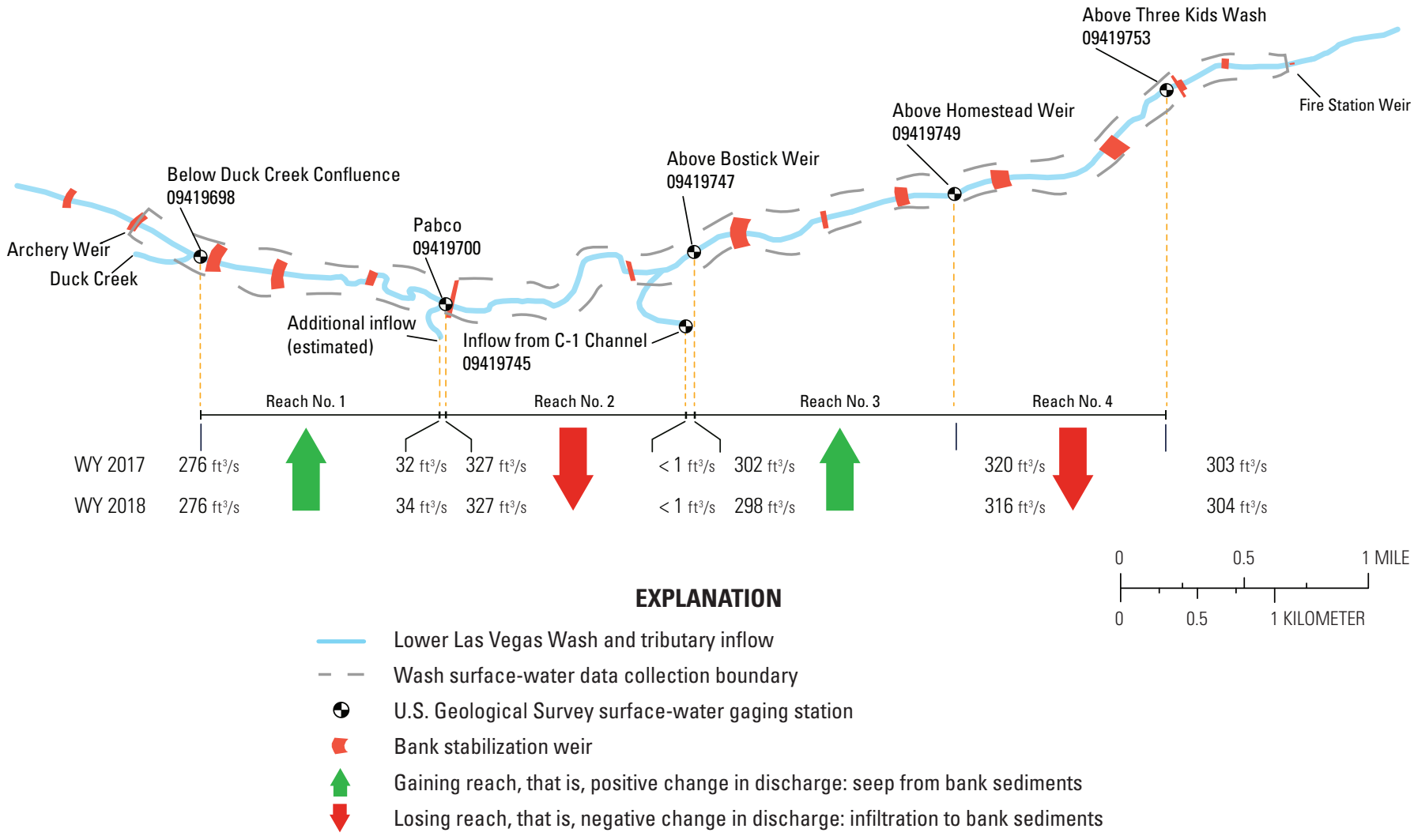

Figure 8. Yearly average discharge in cubic feet per second $\left(\mathrm{ft}^{3} / \mathrm{s}\right)$ at U.S. Geological Survey gaging stations for water years 2017 and 2018, and associated gain to or loss from bank sediments by reach, lower Las Vegas Wash and tributary inflow, Clark County, Nevada.

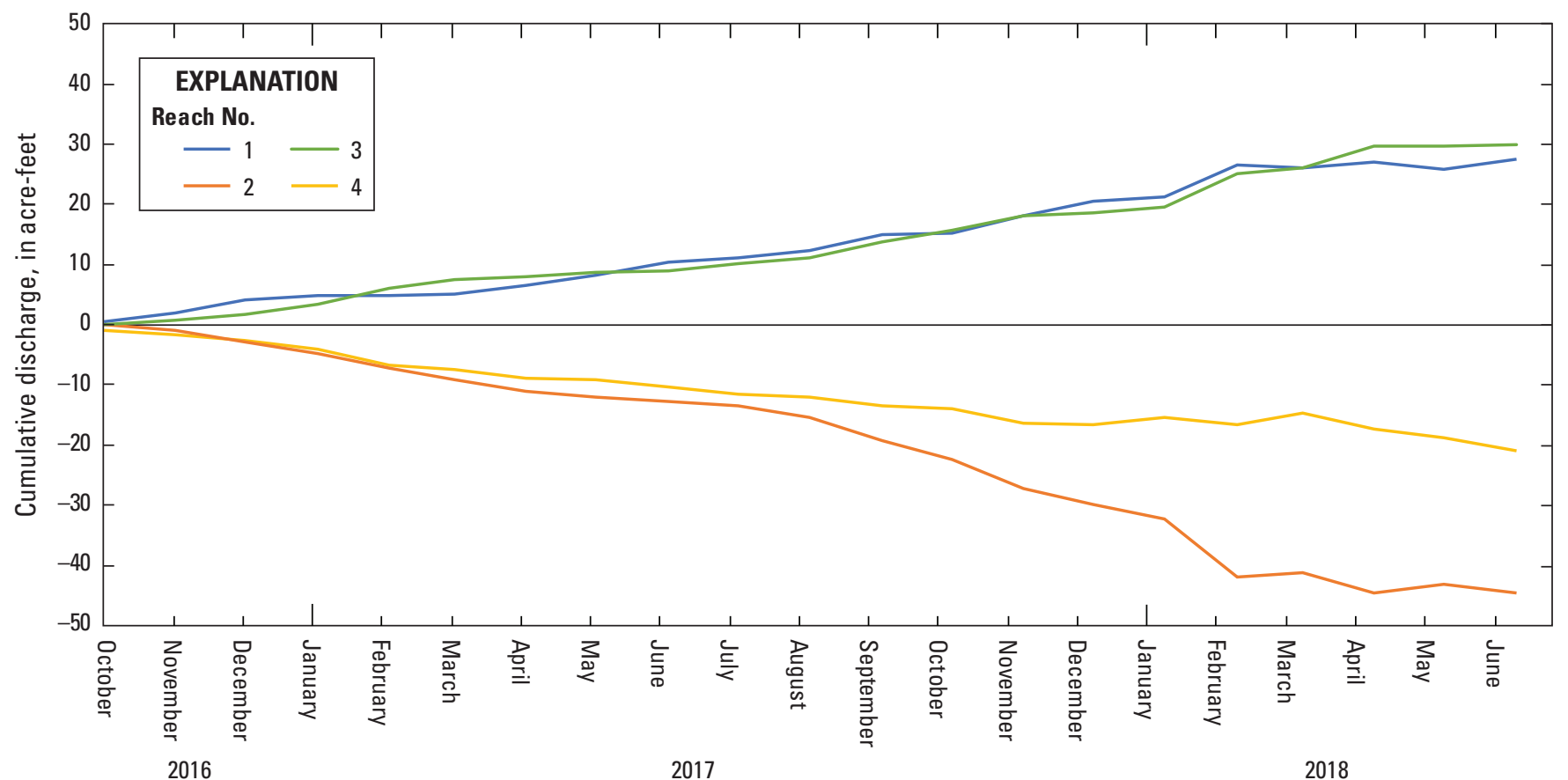

Figure 9. Cumulative change in average monthly discharge at Reaches 1, 2,3, and 4, lower Las Vegas Wash, Clark County, Nevada. 


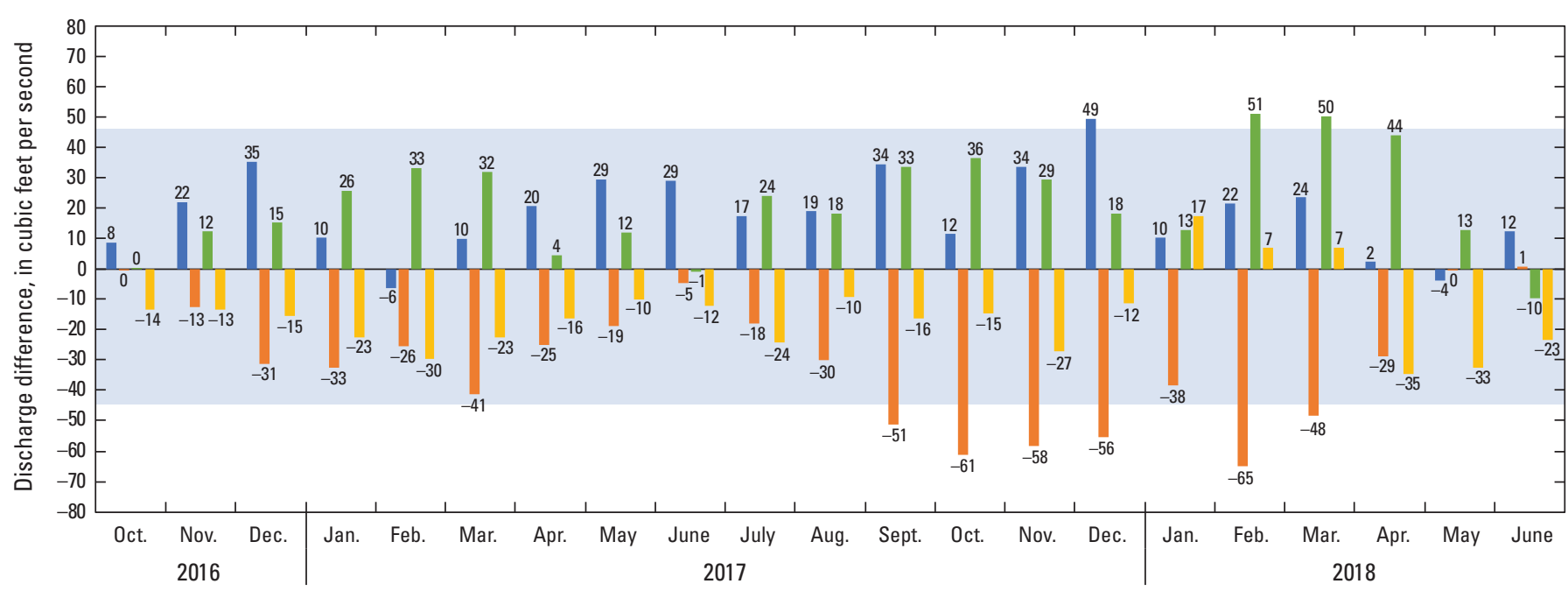

EXPLANATION

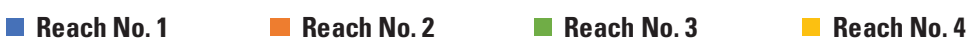

Figure 10. Average monthly discharge difference at Reaches No. 1, 2, 3, and 4 (blue band is average measurement error equal to $+/-15$ percent), lower Las Vegas Wash, Clark County, Nevada.

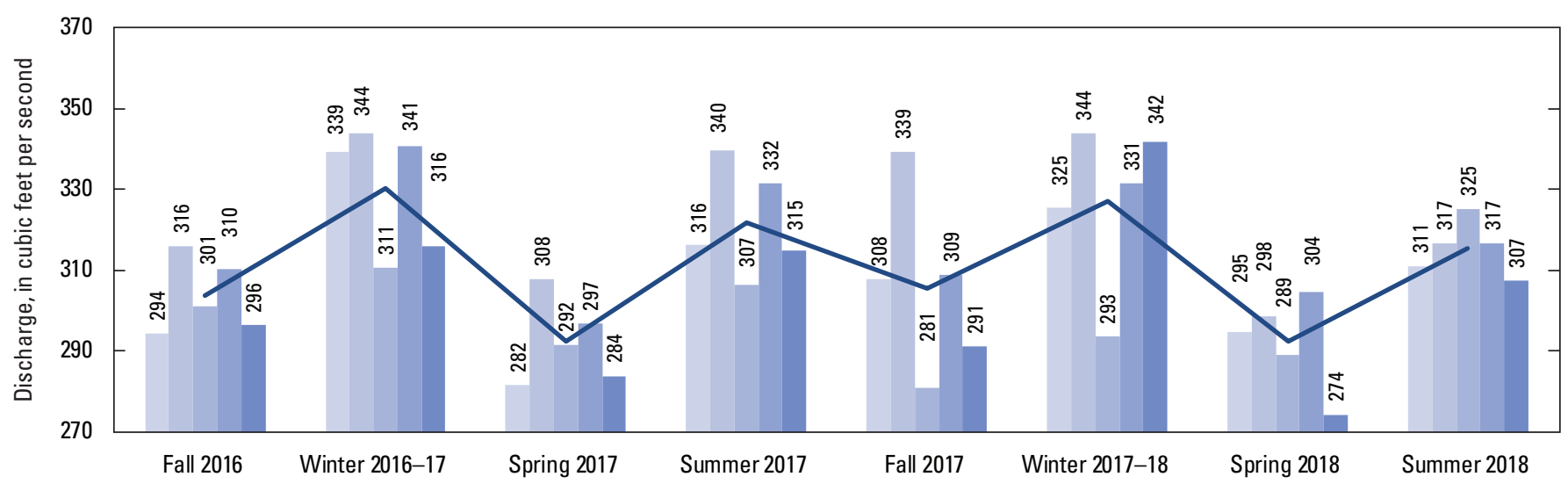

EXPLANATION

Below Duck Creek Confluence 09419698 (includes Basic Magnesium Incorporated groundwater discharge)

Above Bostick Weir 09419747

Above Homestead Weir 09419749
Above Three Kids Wash 09419753

Average total discharge Pabco 09419700

Figure 11. Average seasonal discharge at U.S. Geological Survey gaging stations in the lower Las Vegas Wash, Clark County, Nevada.

increase, a rise in stream stage above the water level in the bank sediments causes streamflow to seep into the channel bank. The magnitude of gain or loss between open channel and bank sediments is proportional to the difference in stream stage and groundwater level. For example, larger differences between stream stage and water levels in the bank sediments occur within Reach No. 1 with correspondingly larger stream gains than within Reach No. 3 where differences between stage and water levels are smaller.
Although Reach No. 4 is losing, some small gains do occur in sections of this reach and the change from a losing to a gaining stream is indirectly defined at points of zero difference in discharge recorded at upstream and downstream gages (fig. 13). As discharge decreases in Reach No. 4, stream stage falls below adjacent groundwater levels at about 290 $\mathrm{ft}^{3} / \mathrm{s}$, creating a new, lowered baseflow elevation for groundwater levels, and initiating gaining streamflow conditions. As discharge increases above about $250 \mathrm{ft}^{3} / \mathrm{s}$, stream stage rises 
above the previously lowered groundwater levels, increasing the baseflow elevation, and initiating losing streamflow conditions. For Reach No. 4, the the minimum and maximum discharge of approximately 250 and $290 \mathrm{ft}^{3} / \mathrm{s}$ defines the range in discharge, or a transition zone, where the reach begins to gain flow from or lose flow to bank sediments. Upstream reaches were each consistently gaining or losing during the period of record analyzed and, therefore, a similar trainsition zone could not be established that defines a range of discharge for initiating gaining or loing streamflow conditions.

Differencing continuous discharge records (downstream minus the upstream records) over a representative 24-hour period for gages bounding Reaches No. 1 through No 4 shows a consistent diurnal pattern and timing of the daily minimum and maximum discharge (fig. 14). For example, during a typical 24-hour diurnal cycle, reaches 1 and 3 are consistently gaining discharge, and reaches 2 and 4 are consistently losing discharge. Moreover, diurnal patterns are similar for all reaches in the timing of minimal differences in discharge at downstream and upstream gages between 9 and 11 a.m, indicating a time period when discharge in the Wash is low (fig. 12) and the greatest potential exists to change gaining or losing streamflow conditions.

\section{Discrete Discharge Measurement Analysis}

Discrete discharge measurements made during four synoptic winter (December) and summer (June) events between 2016 and 2018 were compared to the nearest continuous discharge record to better define and support gaining or losing stream segments. Discharge differences based on continuous discharge records for Reaches No. 1 - 4 were compared to discharge differences for subreaches R1 - R11 (fig. 4) using discrete measurements for June 8, 2017 (table 5). Differences in discharge based on continuous record and discrete measurements ranged from $-1 \mathrm{ft}^{3} / \mathrm{s}$ for Reach No. 4 on June 8,2017 , to $-42 \mathrm{ft}^{3} / \mathrm{s}$ for Reach No. 4 on June 6,2018 . Discrete measurements are not calculated at sites where repeated discrete measurements could not be visually interpolated or frequency of measurements were not sufficient to created a semicontinuous record.

Few discrete subreach summaries (table 5) are available because of limited observed or interpolated discrete discharge data for computing differences in subreach discharge; however, reach differences are computed for measurements collected on June 8, 2017, and for Reach No. 4 during the December 8, 2017, and June 8, 2018, data collection events. Discete discharge measurements collected on December 8 , 2016, produced discharge differences for two subreaches (R-1 and R-4). Three additional locations were measured on June 8, 2017, and produced discharge differences for 11 subreaches. Discrete measurements made in December 2017 and June 2018 were completed at the same locations as the first two synoptic data-collection efforts, except where sections had been disturbed by new construction, resulting in discharge differences for six and five subreaches, respectively (table 5). 


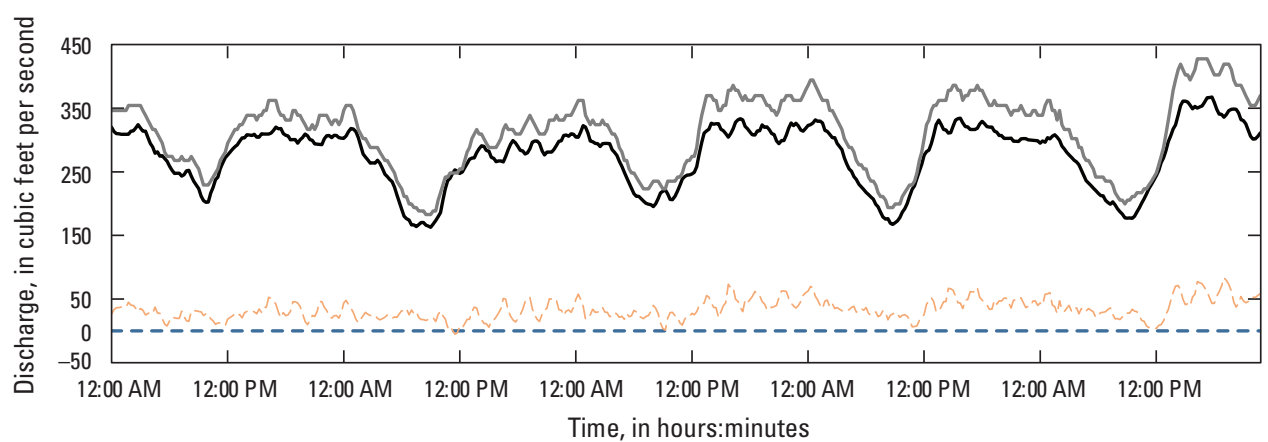

EXPLANATION

USGS surface-water gaging stations Duck Creek Confluence 09419698 Pabco 09419700 Discharge difference

- - - Zero discharge difference line

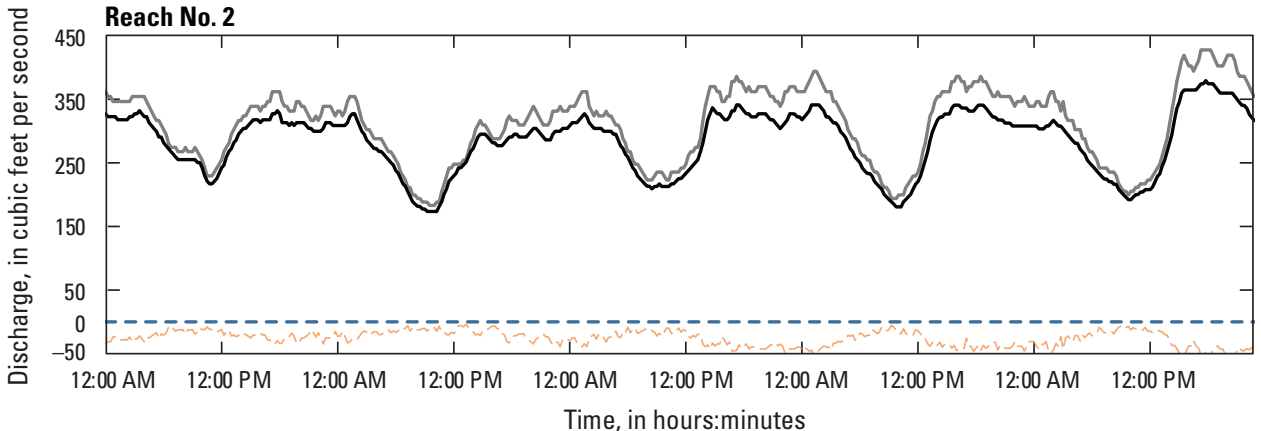

\section{EXPLANATION}

USGS surface-water gaging stations Above Bostick Weir 09419747

Pabco 09419700

Discharge difference

- . - Zero discharge difference line

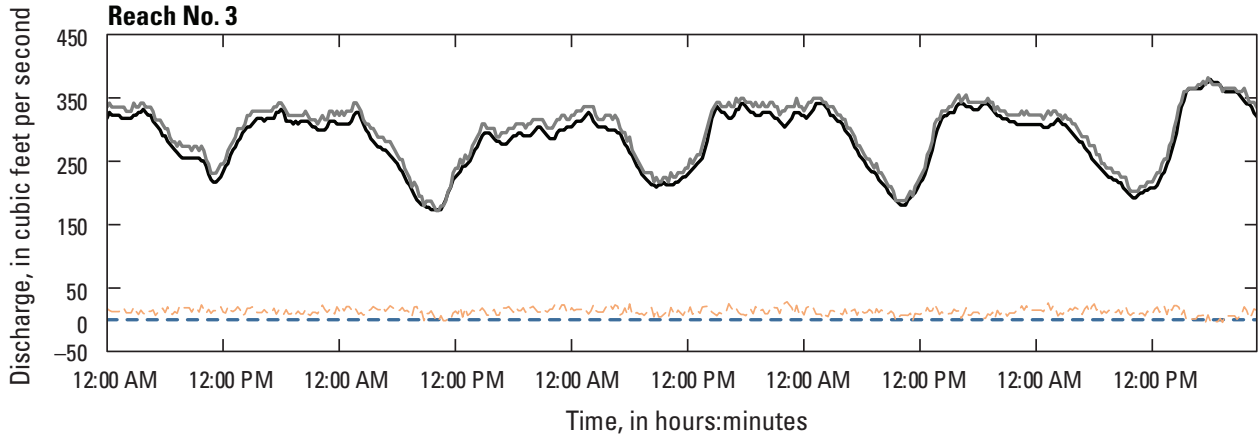

\section{EXPLANATION}

USGS surface-water gaging stations Above Bostick Weir 09419747 Above Homestead Weir 09419749 Discharge difference

- - - Zero discharge difference line

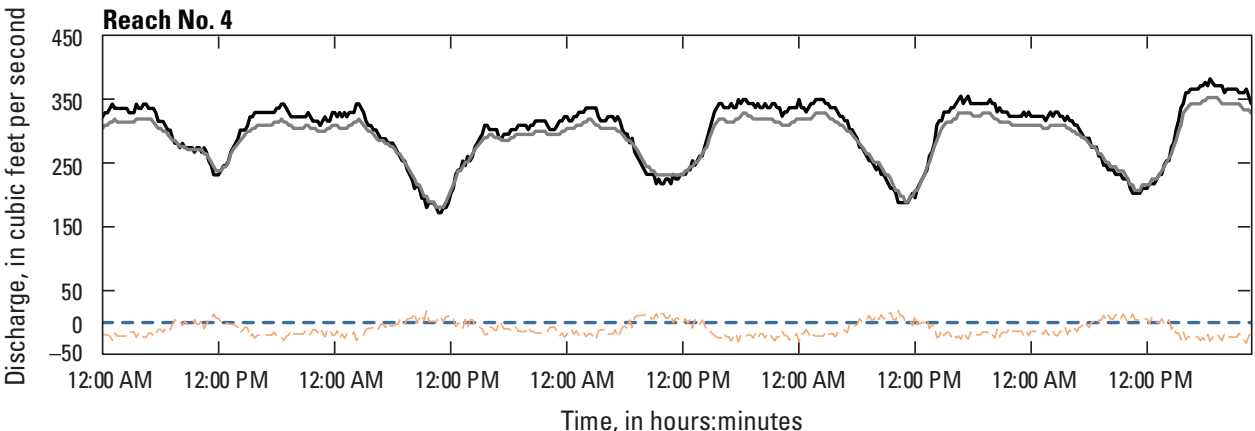

EXPLANATION

USGS surface-water gaging stations

Above Three Kids Wash 09419753 Above Homestead Weir 09419749

- - - Zero discharge difference line

Figure 12. Daily diurnal stream discharge record for U.S. Geological Survey (USGS) surface-water gaging stations and associated stream reach (December 6-10, 2016), lower Las Vegas Wash, Clark County, Nevada. 


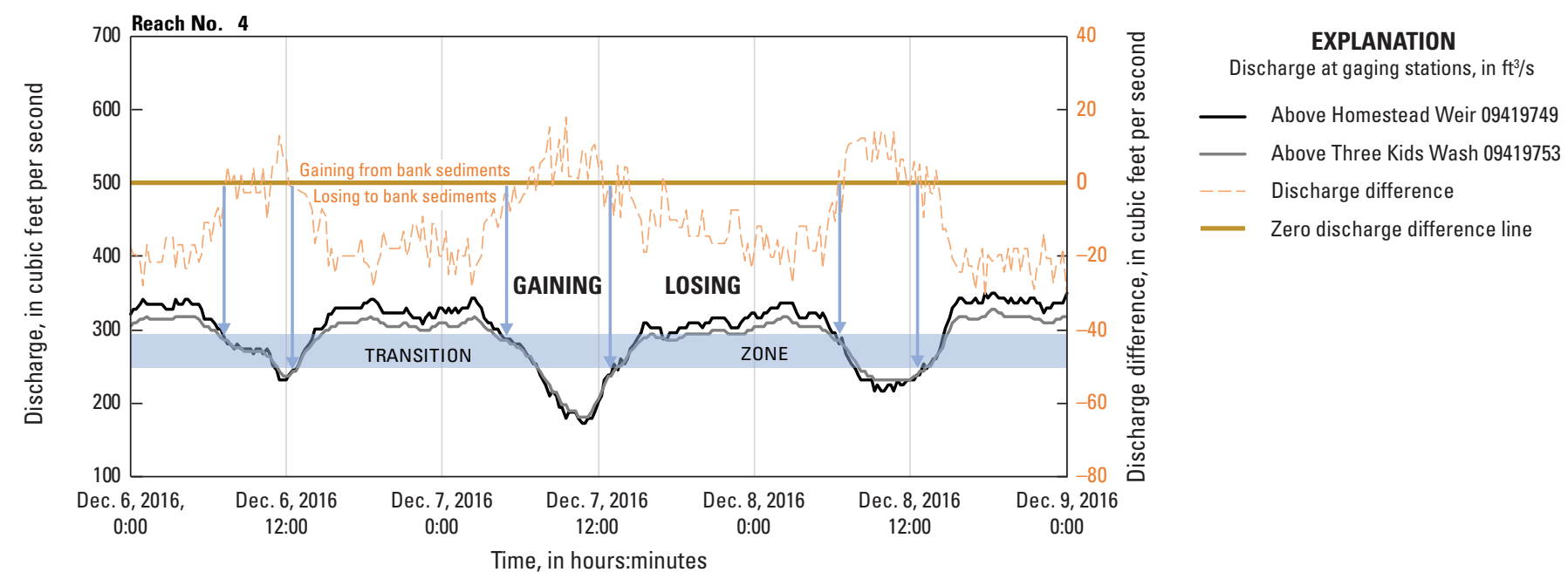

Figure 13. Stream discharge (left $y$-axis) and difference in stream discharge (right $y$-axis) for downstream and upstream gages defining Reach No. 4, lower Las Vegas Wash, Clark County, Nevada. Blue arrows indicate minimum and maximum discharge range for interpreted transition zone of surface-water and groundwater interaction.

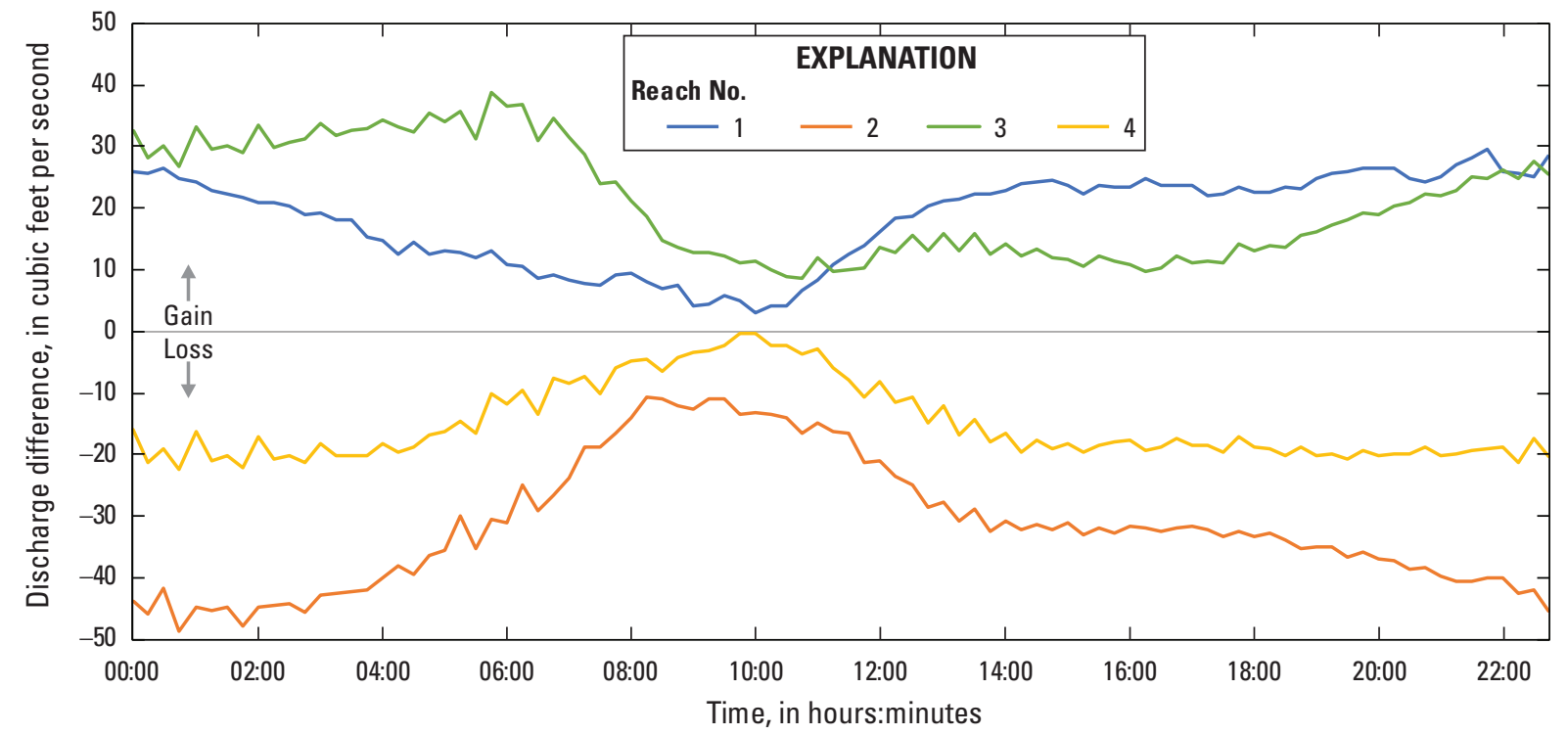

Figure 14. Average daily difference in discharge record at Reach No. 1, No. 2, No. 3, and No. 4 (October 2016 through June 2018), lower Las Vegas Wash, Clark County, Nevada. 
Table 5. Change in discharge at select reaches along the lower Las Vegas Wash, Clark County, Nevada.

[Reach ID from figure 5. Abbreviations: $\mathrm{ft}^{3} / \mathrm{s}$, cubic feet per second; - , not available]

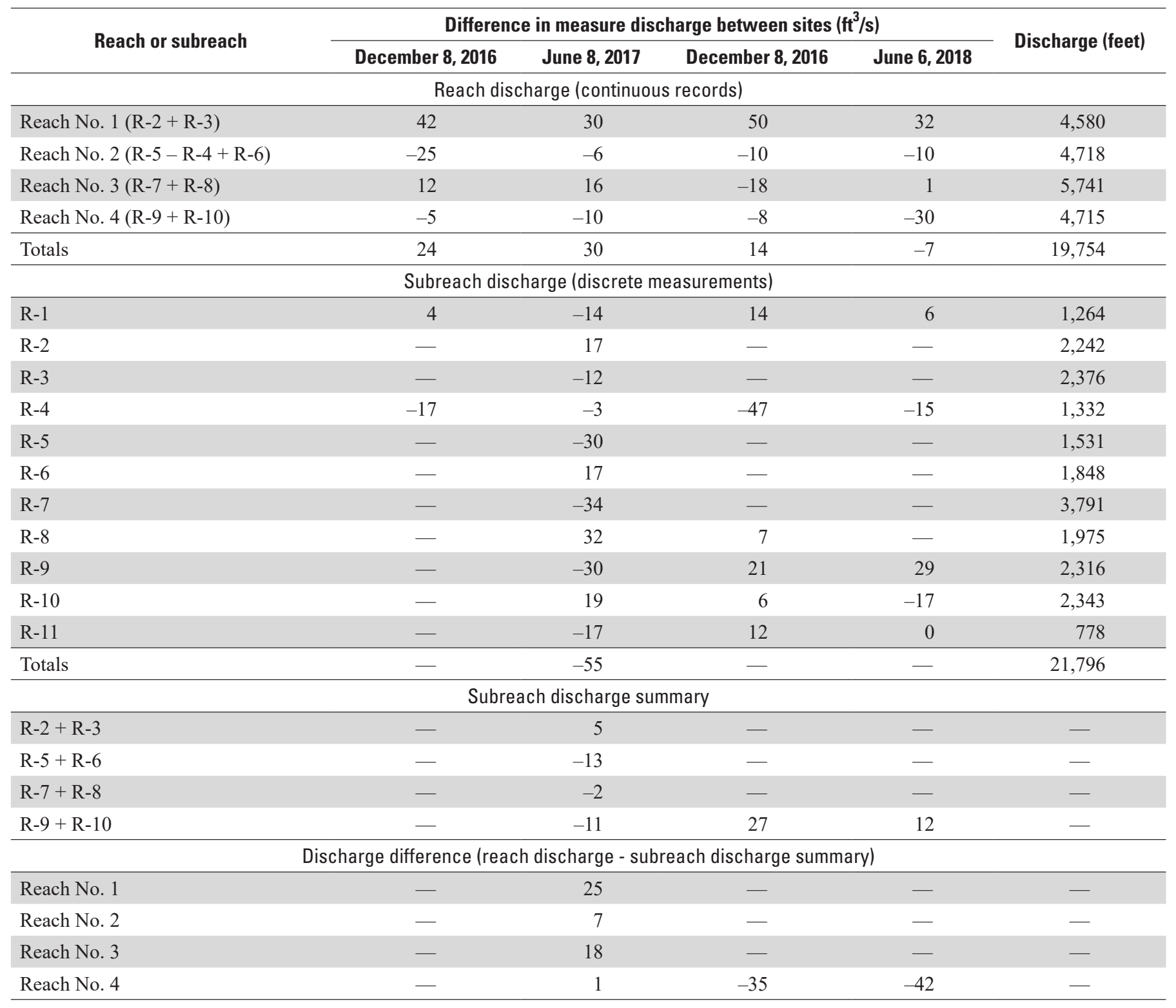




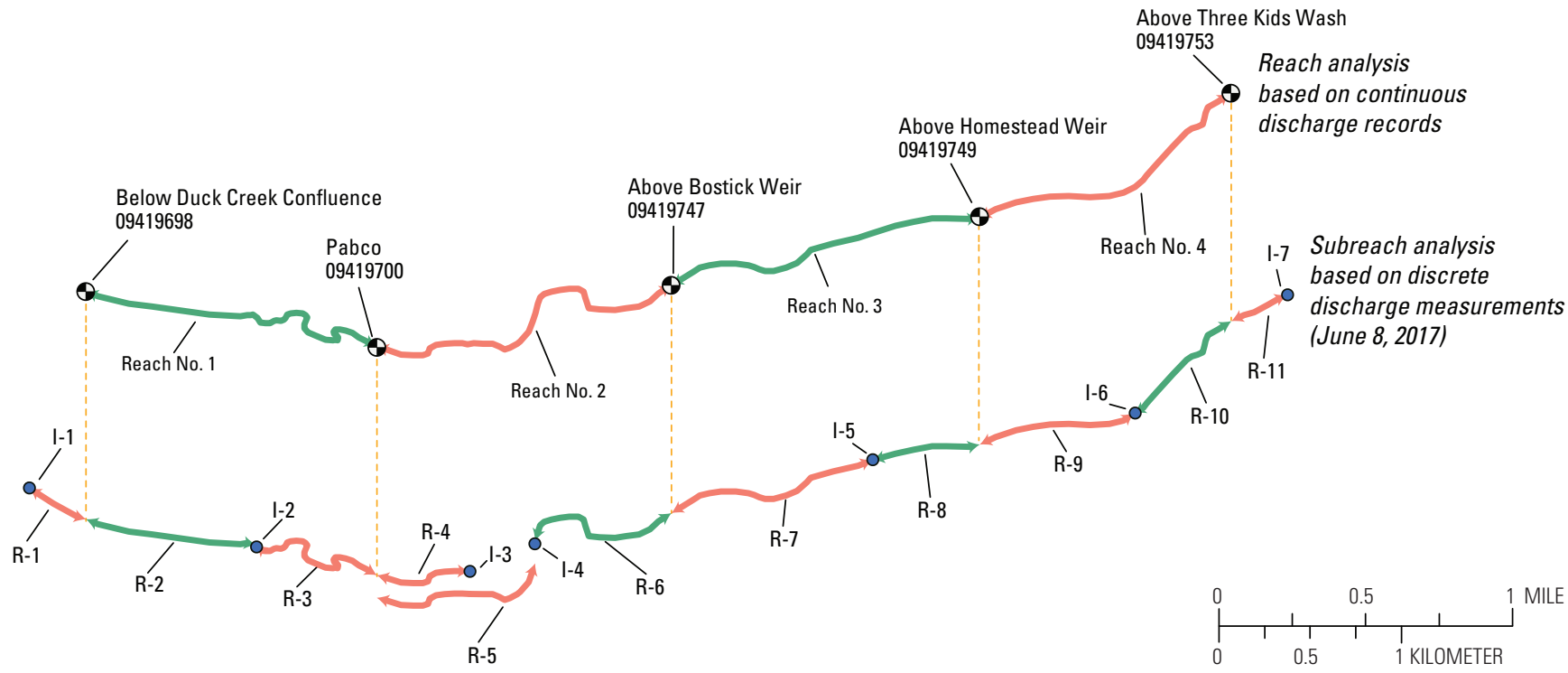

EXPLANATION

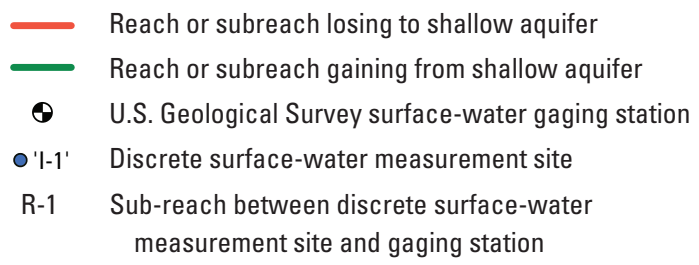

Figure 15. Discharge gain and loss for reaches and subreaches along the lower Las Vegas Wash, Clark County, Nevada.

\section{Surface-Water-Groundwater Interaction}

Surface-water and groundwater interaction is commonly driven by regional topography (Cardenas, 2007) and smaller local interaction from streambed hydraulic properties, topography, channel sinuosity (Cardenas and others, 2004; Cardenas and Wilson, 2007; and Boano and others, 2006), and erosion control structures. Regional influences on surface-water and groundwater interaction at the Wash include regional groundwater flow, reservoir stage at nearby Lake Mead, and local groundwater pumping. All of these processes influence the water-level altitude of bank sediments, and relative to streamflow stage, cause surface-water and groundwater interactions along reaches and subreaches in the Wash. However, evaluating the dynamics of local-scale and regional processes that influence streamflow discharge in the Wash are outside the scope of this study.

The computed gain and loss in discharge from discrete measurements provide higher spatial detail between continuous gages, and suggest that shorter areas of inflow and outflow exist in the channel-bank sediment system. Average discharge gain and loss for reaches are estimated from continuous records collected between 2016 and 2018, and for subreaches are estimated from discrete measurements collected on June 8, 2017, during synoptic measurement events at sites I-1 through I-7. Continuous and discrete measuements show that smaller-scale differences occur at individual subreaches compared to larger-scale reaches between gaging stations (fig. 15). Differences in estimated discharge gains or losses for subreaches and reaches likely are due to the length of period analyzed and the associated error at each measurement location. Average discharge gain or loss for subreaches based on discrete measurements show notable differences compared to continuous records at subreachs R-3, R-6, R-7, and R-10. However, none of these four subreaches dominate the overall gain or loss that occurs within each respective reach. For example, continuous discharge records for Reach No. 4 show a mostly losing section, and discrete measurements suggest that the discharge loss within subreach R-9, and not R-10, dominate the overall loss estimated for this reach. Similarly, discrete discharge measurements suggest that discharge gains or losses occurring in subreaches R-2, R-5, and R-8 dominate the overall gain or loss for each respective reach. Results from other synoptic runs, however, are less clear and are very close to the level of uncertainty noted for individual discharge measurements. 
Table 6. Altitude of surface water at U.S. Geological Survey gaging stations from Global Navigation Satellite Systems (GNSS) survey conducted March to June 2018, lower Las Vegas Wash, Clark County, Nevada.

[USGS, U.S. Geological Survey; ID, identification; DMS, degree minute second; NAVD 88, North American Vertical Datum of 1988]

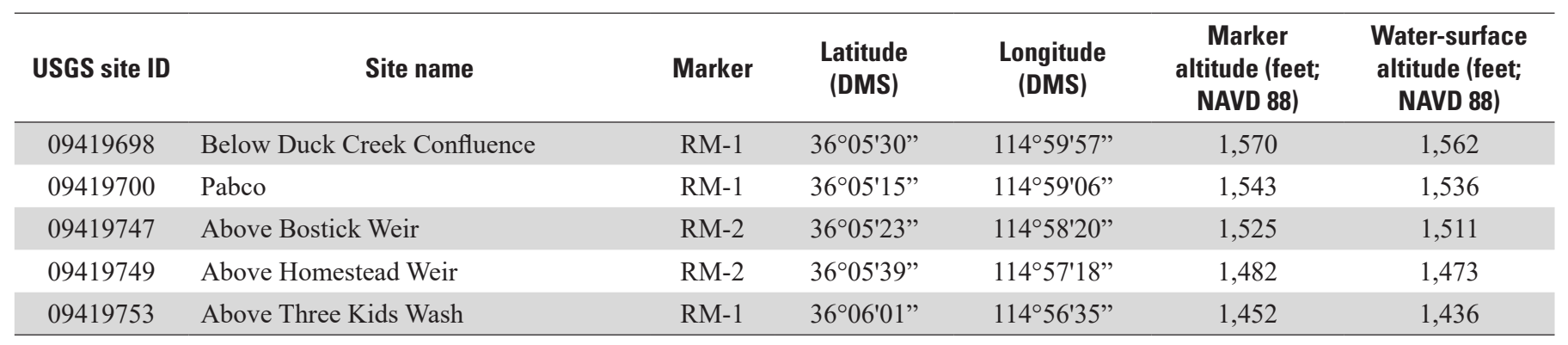

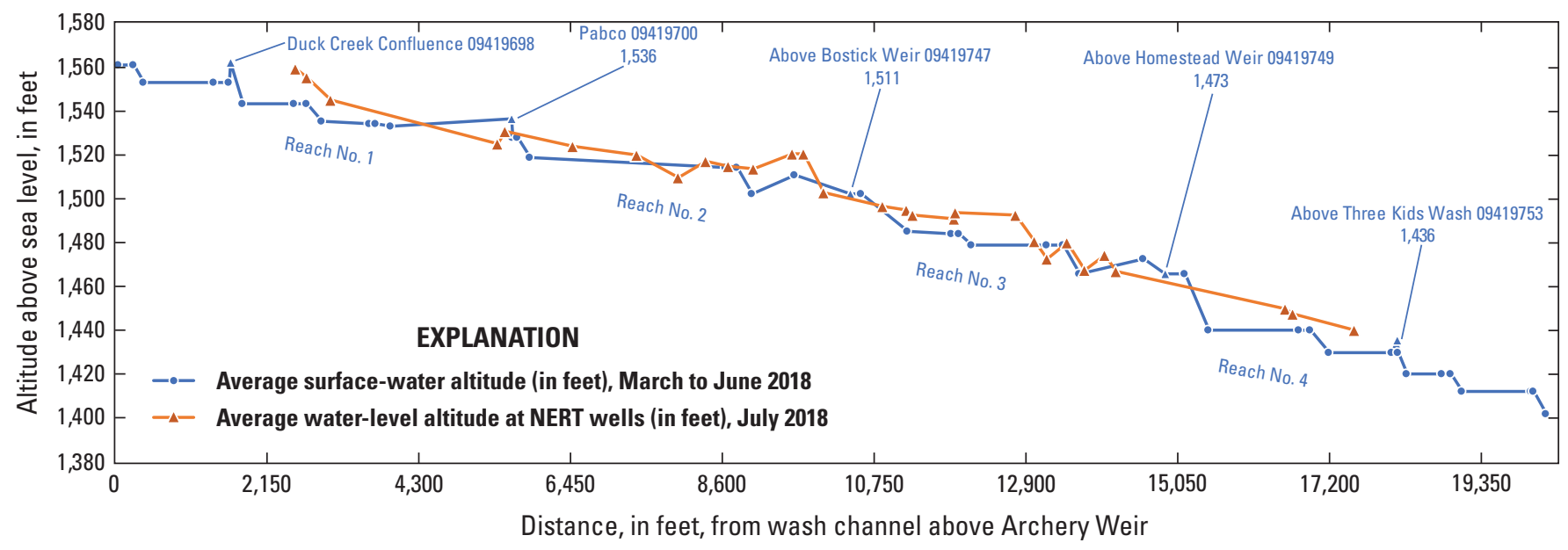

Figure 16. Approximate surface-water and groundwater longitudinal profiles from water-level altitudes at U.S. Geological Survey gaging stations, discrete measurement sites, and nearby wells, lower Las Vegas Wash, Clark County, Nevada.

\section{Groundwater Levels}

Groundwater levels collected by NERT (Nevada Environmental Response Trust, 2018) provide information on the proximity of groundwater to surface-water altitudes along the Wash. A USGS Global Navigation Satellite Systems (GNSS) survey on gage datum points at continuous gaging stations, completed between March and June 2018, establish the altitude of the mean water surface (table 6). Additional surface-water and groundwater altitudes were collected using a handheld Global Positioning System (GPS) for the water surface at multiple discrete measurement site locations (for measurements collected in June 2018) and for water levels in wells. GNSS and GPS data were used to develop surfacewater and groundwater altitude profiles for graphical comparison (fig. 16). The water-level profiles collected in June and July of 2018 showed the close proximity of the groundwater altitude to surface-water stage and further suggest gain and loss of water in the open channel, as previously discussed, are likely. However, the location of groundwater sites often were not in close proximity to continuous gaging stations or discrete measurement surface-water sites. As a result, only a general correlation of stage and water-level altitude to determine gains and losses along stream reaches and subreaches was possible.

Continuous groundwater levels in the study area (fig. 17) and diurnal fluctuations of water levels in six wells were graphically compared to stage record in the Wash near Duck Creek Confluence (U.S. Geological Survey, 2018g) and at Reach No. 2 and Reach No. 4 (fig. 18). Stage records at Reach No. 2 and Reach No. 4 were generated by averaging the the records for the two corresponding continuous gaging stations for each respective reach, and then time-adjusting the averaged stream record to match continuous water-level data from NERT monitoring wells that are located mid-reach and on opposite banks of the Wash (fig. 17). Water-level changes in selected wells show a time-lagged correlation with changes in stage (fig. 18). The average time-lag between a change in stage and a response in the water level was about 3 hours, with wells on the north bank reacting sooner to changes in surface-water stage than wells on the south bank. Differences in reaction time north and south of the Wash are likely due to the dynmaics of the groundwater flow system in the area; however, evaluating these processes are beyond the scope of the study. 


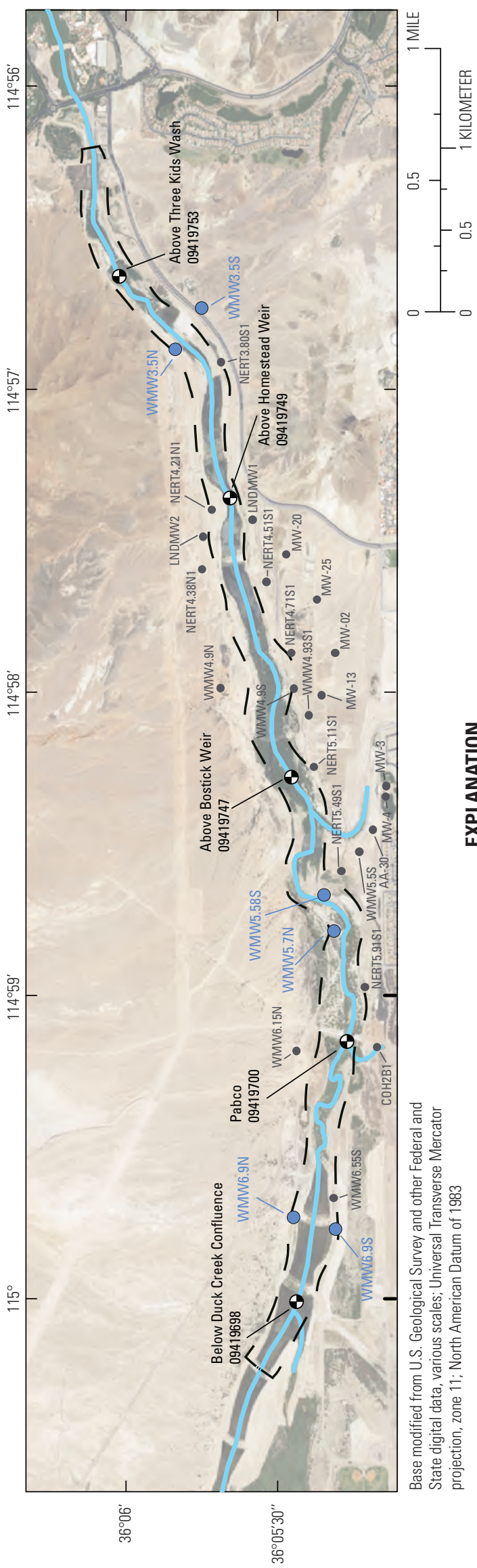

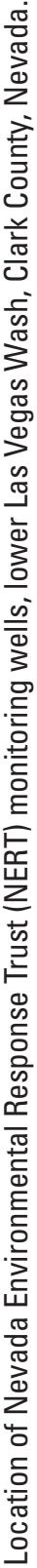

흘 

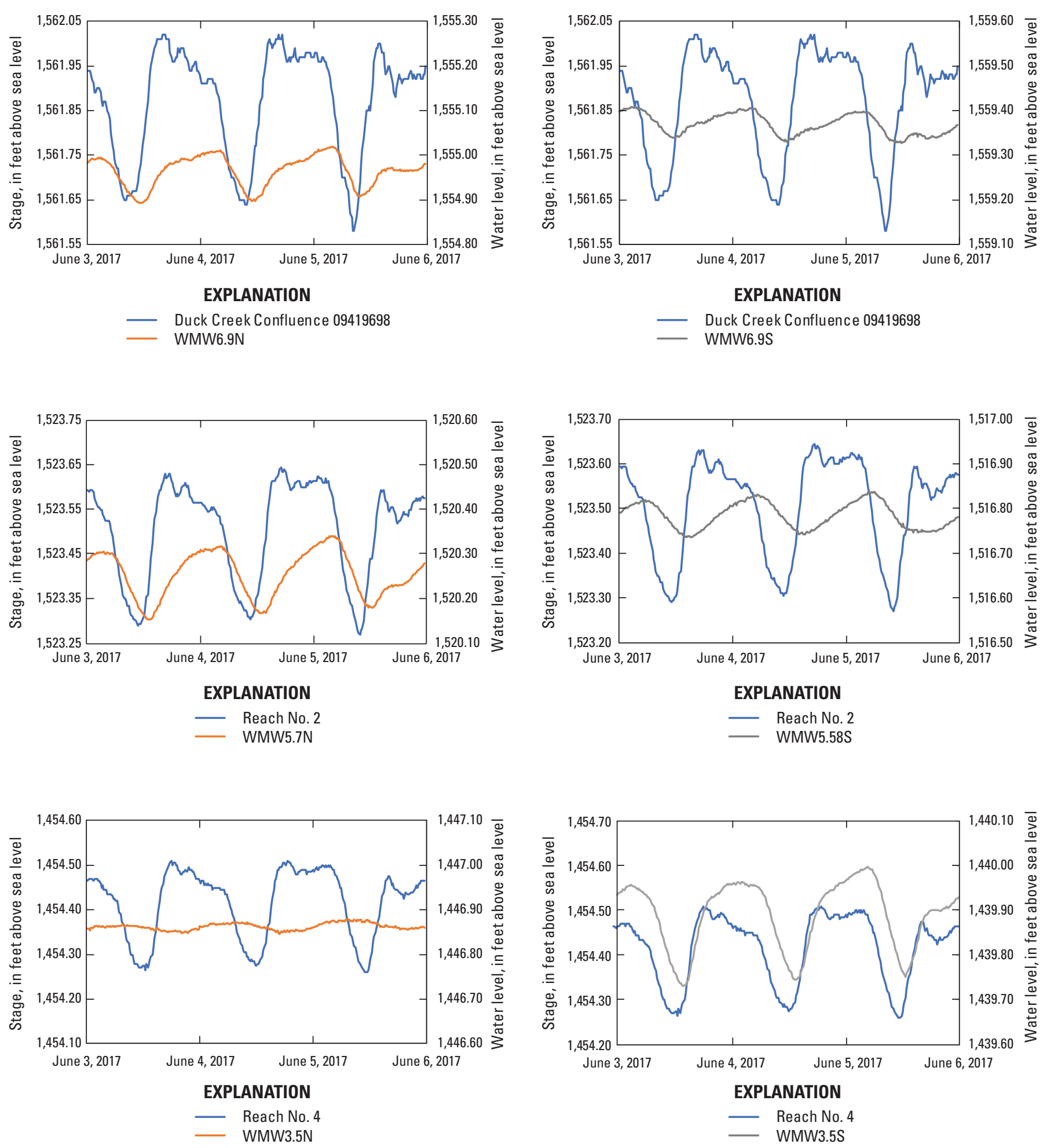

Figure 18. Hydrographs of stage for Duck Creek Confluence gaging station, Reaches No. 2 and 4, and water levels in selected Nevada Environmental Response Trust wells, June 3-June 6, 2017, lower Las Vegas Wash and tributary inflow, Clark County, Nevada. 


\section{Summary}

In 2016, the U.S. Geological Survey (USGS) and the Nevada Division of Environmental Protection (NDEP) began a study to evaluate the change in discharge in a segment of the Lower Las Vegas Wash to enhance the understanding of the exchange between surface-water discharge and groundwater through adjacent bank sediments. This report describes the methods used to collect and evaluate discharge data along a 4-mile reach of the lower Las Vegas Wash (referred to as the Wash) between 2016 and 2018. Data collected included continuous discharge records from five USGS gaging stations and discrete measurements made during the summer and winter months. Ancillary groundwater levels provided by the Nevada Environmental Response Trust (NERT) were also compiled, organized, and used to support this analysis.

Discharge hydrographs for five continuous USGS gaging stations and seven discrete measurements sites were constructed and time-lagged. Discharge data from time-lagged downstream sites were subtracted from uncorrected upstream sites, and resulting differences defined as channel gain from bank sediments orchannel loss to bank sediments. For descriptive purposes, the Wash was divided into four longer reaches between gaging stations and eleven shorter subreaches between discrete measurement sites and gaging stations. Gain and loss during the 2016-2018 study period are described for each reach and subreach.

Streamflow discharge in the lower Las Vegas Wash was predominantly gaining in Reaches No. 1 and No. 3 and losing in Reaches No. 2 and No. 4. Analysis of streamflow discharge gain or loss based on discrete measurements indicate that subreaches R-2, R-5, R-8, and R-9 domanate the overall gain or loss for reaches $1,2,3$, and 4, respectively. Grade-control weirs and channel sinuosity contribute to the locations of surface water gains from or losses to the bank sediment. Seasonal variations in discharge are likely caused by changes in municipal water-use, periodic flow peaks from flooding, and seasonal effects from evapotranspiration. Discrete measurements collected during synoptic measurement events were similar in trend and accuracy to discharge data collected at continuous gaging stations.

Change in water levels from wells completed in the adjacent shallow aquifer are similar in pattern and trend to the changes in surface-water stage. The diurnal pattern was compared between surface water and groundwater, and a timelag of approximately 3 hours was observed between changes in stage at stream gaging stations and water-level changes in nearby wells. Moreover, wells on the north bank of the Wash react sooner to changes in surface-water stage than wells on the south bank. Comparing surface-water and groundwater altitude profiles along the lower Las Vegas Wash shows a general correlation between stage and water levels in wells. However, due mainly to the distance between wells and gaging stations, differences in altitude profiles are less accurate than differences in discharge hydrographs for continuous and discrete measurement sites for determining gains or losses along the Wash.

Discharge and groundwater levels in the area are dynamic and the current study captures only a two-year snapshot of average conditions, discharge differences, and associated gains and losses along the Wash. Changes to the morphology of the stream channel will affect travel time and volume of gain and loss. Finally, regional or local conditions that likely affect surface-water and groundwater dynamics and interactions along the Wash, such as regional groundwater flow, reservoir stage at nearby Lake Mead, local groundwater pumping, or changes in volumes of treated effluent, may alter the environmental conditions presented in this study.

\section{References Cited}

American Society for Testing and Materials, 2013, Standard test method for open-channel flow measurement by acoustic velocity meter systems: Active Standard ASTM D5389, v. 11.01, https://www.astm.org/Standards/D5389.htm.

Boano, F., Camporeale, C., Revelli, R., and Ridolfi, L., 2006, Sinuosity-driven hyporheic exchange in meandering rivers: Geophysical Research Letters, v. 33, no. 18, 4 p., https://doi.org/10.1029/2006GL027630.

Bureau of Reclamation, 1982, Status report-Las Vegas Wash unit: Nevada, Colorado River Basin Salinity Control Project, Lower Colorado Region, Boulder City, 53 p.

Capesius, J.P., and Arnold, L.R., 2012, Comparison of two methods for estimating base flow in selected reaches of the South Platte River, Colorado: U.S. Geological Survey Scientific Investigations Report 2012-5034, 20 p., https://doi.org/10.3133/sir20125034.

Cardenas, M.B., 2007, Potential contribution of topographydriven regional groundwater flow to fractal stream chemistry-Residence time distribution analysis of Toth flow: Geophysical Research Letters, v. 34, no. 5, 5 p., https://doi.org/10.1029/2006GL029126.

Cardenas, M.B., and Wilson, J.L., 2007, Dunes, turbulent eddies, and interfacial exchange with permeable sediments: Water Resources Research, v. 43, no. 8, 16 p., https://doi.org/10.1029/2006WR005787.

Cardenas, M.B., Wilson, J.L., and Zlotnik, V.A., 2004, Impacts of heterogeneity, bed forms, and stream curvature on subchannel hyporheic exchange: Water Resources Research, v. 40, no. 8, 14 p., https://doi.org/10.1029/2004WR003008. 
Chesner, W.H., and Pai, M., 1981, Hourly diurnal flow variations in publicly-owned wastewater treatment facilities: U.S. Environmental Protection Agency, EPA-600/ S2-81-218, 4 p.

Duan, J.G., and Scott, S., 2007, Selective bed-load transport in Las Vegas Wash, a gravel-bed stream: Journal of Hydrology (Amsterdam), v. 342, no. 3-4, p. 320-330, https://doi.org/ 10.1016/j.jhydrol.2007.06.001.

ENSR International, 2005, Conceptual site model, KerrMcGee facility: Henderson, Nevada, document no. 04020-023-100, 77 p., accessed August 2019 at https:// nertjoomla3.azurewebsites.net/index.php/projectdocuments/access-project-documents/Reports.

Halford, K.J., Garcia, C.A., Fenelon, J.M., and Mirus, B.B., 2012, Advanced methods for modeling water-levels and estimating drawdowns with SeriesSEE, an Excel add-in (ver. 1.1, July 2016): U.S. Geological Survey Techniques and Methods 4-F4, 28 p., https://doi.org/10.3133/tm4f4.

Harlan, S.L., Yabiku, S.T., Larsen, L., and Brazel, A.J., 2009, Household water consumption in an arid cityAffluence, affordance, and attitudes: Society \& Natural Resources, v. 22, no. 8, p. 691-709, https://doi.org/10.1080/ 08941920802064679.

Kennard, M.J., Mackay, S.J., Pusey, B.J., Olden, J.D., and Marsh, N., 2010, Quantifying uncertainty in estimation of hydrologic metrics for ecohydrological studies: River Research and Applications, v. 26, no. 2, p. 137-156, https://doi.org/10.1002/rra.1249.

Kennedy, E.J., 1983, Computation of continuous records of streamflow, chap. A13 in Book 3, Applications of hydraulics: U.S. Geological Survey Techniques of WaterResources Investigations 3-A13, 53 p., https://doi.org/ 10.3133/twri03A13.

Las Vegas Wash Coordination Committee, 2018, Water-quality research monitoring program: Las Vegas Wash Coordination Committee web page, accessed July 2018 at https://www.1 vwash.org/html/being_done_research.html.

Lizárraga, J.S., and Wehmeyer, L.L., 2012, Estimation of streamflow gains and losses in the lower San Antonio River watershed, south-central Texas, 2006-10: U.S. Geological Survey Scientific Investigations Report 2012-5073, 34 p., https://doi.org/10.3133/sir20125073.

Morris, F.A., and Paulson, L.J., 1983, Water quality trends in the Las Vegas Wash wetlands: Aquatic Resource Management of the Colorado River Ecosystem, p. 125-136, https://digitalscholarship.unlv.edu/water_pubs/34.
MWH, 2005, Basic Remediation Company health and safety plan; BMI Common Areas, Clark County, Nevada (October 2005): Technical report prepared for Basic Remediation Company, 141 p., accessed July 2017 at http://citeseerx.ist.psu.edu/viewdoc/download?doi= 10.1.1.473.8494\&rep=rep1\&type=pdf.

Mueller, D.S., Wagner, C.R., Rehmel, M.S., Oberg, K.A., and Rainville, F., 2013, Measuring discharge with acoustic Doppler current profilers from a moving boat (ver. 2.0, December 2013): U.S. Geological Survey Techniques and Methods, book 3, chap. A22, 95 p., https://doi.org/10.3133/ tm3A22.

Nevada Environmental Response Trust, 2018, Program background and status: Nevada Environmental Response Trust web page, accessed July 2018 at https://ndep.nv.gov/ environmental-cleanup/black-mountain-industrialbmi-complex.

Rantz, S.E., 1982, Computation of discharge, of Rantz, S.E, Measurement and computation of streamflow: U.S. Geological Survey Water Supply Paper 2175, v. 2, p. 285-631, https://doi.org/10.3133/wsp2175.

Roline, R., and Sartoris, J., 1984, Las Vegas Wash advanced water quality study - Final report: Bureau of Reclamation, 119 p., https://digitalscholarship.unlv.edu/water_pubs/85.

Roline, R., and Sartoris, J., 1997, Las Vegas Wash water quality monitoring program, 1996 report of findings: Bureau of Reclamation Technical Memorandum No. 8220-97-8, 43 p.

Smith, P.N., Yu, L., McMurry, S.T., and Anderson, T.A., 2004, Perchlorate in water, soil, vegetation, and rodents collected from the Las Vegas Wash, Nevada: Environmental Pollution, v. 132, no. 1, p. 121-127, https://doi.org/10.1016/ j.envpol.2004.03.017.

Southern Nevada Water Authority, 2018a, Water quality research: Southern Nevada Water Authority web page, accessed July 2019 at https://www.snwa.com/water-quality/ research/index.html.

Southern Nevada Water Authority, 2018b, Water resource portfolio: Southern Nevada Water Authority web page, accessed May 2019 at https://www.snwa.com/water-resources/ preparing-future/index.html.

Turnipseed, D.P., and Sauer, V.B., 2010, Discharge measurements at gaging stations: U.S. Geological Survey Techniques and Methods book 3, chap. A8, 87 p., https://doi.org/10.3133/tm3A8.

Urbansky, E.T., Magnuson, M.L., Kelty, C.A., and Brown, S.K., 2000, Perchlorate uptake by salt cedar (Tamarix ramosissima) in the Las Vegas Wash riparian ecosystem: Science of the Total Environment, v. 256, no. 2-3, p. 227-232, https://doi.org/10.1016/S0048-9697(00)00489-7. 
U.S Census Bureau, 2020, American Community Survey data available on the World Wide Web, accessed August 15, 2018, at https://data.census.gov/cedsci/.

U.S. Environmental Protection Agency, 2011, Drinking water-Regulatory determination on Perchlorate: 40 CFR Part 141, v. 76, no. 29, p. 7762-7767, https://www.gpo.gov/ fdsys/pkg/FR-2011-02-11/html/2011-2603.htm.

U.S. Geological Survey, 2018, USGS water data for the Nation: U.S. Geological Survey National Water Information System database, accessed July 2, 2018, at https://doi.org/ 10.5066/F7P55KJN.

U.S. Geological Survey, 2018a, USGS 09419679 LAS VEGAS WASTEWAY NR E LAS VEGAS, NV, in USGS water data for the Nation: U.S. Geological Survey National Water Information System database, accessed July 2, 2018, at https://waterdata.usgs.gov/nwis/inventory/?site_no= 09419679.

U.S. Geological Survey, 2018b, USGS 09419700 LAS VEGAS WASH AT PABCO RD NR HENDERSON, NV, in USGS water data for the Nation: U.S. Geological Survey National Water Information System database, accessed July 2, 2018, at https://waterdata.usgs.gov/nwis/inventory/? site_no $=09419700$.

U.S. Geological Survey, 2018c, USGS 09419753 LV WASH ABV THREE KIDS WASH BLW HENDERSON, NV, in USGS water data for the Nation: U.S. Geological Survey National Water Information System database, accessed July 2, 2018, at https://waterdata.usgs.gov/nwis/inventory/? site_no $=09419753$.

U.S. Geological Survey, 2018d, USGS 09419800 LV WASH BLW LAKE LAS VEGAS NR BOULDER CITY, NV, in USGS water data for the Nation: U.S. Geological Survey National Water Information System database, accessed July 2, 2018, at https://waterdata.usgs.gov/nwis/inventory/? site_no $=09419800$.
U.S. Geological Survey, 2018e, USGS 09419696 DUCK CK AT BROADBENT BLVD AT E LAS VEGAS, NV, in USGS water data for the Nation: U.S. Geological Survey National Water Information System database, accessed July 2, 2018, at https://waterdata.usgs.gov/nwis/inventory/? site no $=09419696$.

U.S. Geological Survey, 2018f, USGS 09419747 LV WASH ABV BOSTICK WEIR NR HENDERSON, NV, in USGS water data for the Nation: U.S. Geological Survey National Water Information System database, accessed July 2, 2018, at https://waterdata.usgs.gov/nwis/inventory/?site_no= 09419747.

U.S. Geological Survey, 2018g, USGS 09419698 LV WASH BLW DUCK CK CONF NR HENDERSON, NV, in USGS water data for the Nation: U.S. Geological Survey National Water Information System database, accessed July 2, 2018, at https://waterdata.usgs.gov/nwis/inventory/?site_no= 09419698.

U.S. Geological Survey, 2018h, USGS 09419749 LV WASH ABV HOMESTEAD WEIR NR HENDERSON, NV, in USGS water data for the Nation: U.S. Geological Survey National Water Information System database, accessed July 2, 2018, at https://waterdata.usgs.gov/nwis/inventory/? site_no $=09419749$.

Wahl, K.L., Wilbert, O.T., and Hirsch, R.M., 1995, The stream-gaging program of the U.S. Geological Survey: U.S. Geological Survey Circular 1123, 22 p., https://doi.org/ $10.3133 / \operatorname{cir} 1123$.

Whitney, J.W., Glancy, P.A., Buckingham, S.E., and Ehrenberg, A.C., 2015, Effects of rapid urbanization on streamflow, erosion, and sedimentation in a desert stream in the American Southwest: Anthropocene, v. 10, p. 29-42, https://doi.org/10.1016/j.ancene.2015.09.002.

Wilson, J.W., 2021, Trace of the lower Las Vegas Wash study area, 2017: U.S. Geological Survey data release, https://doi.org/10.5066/P9UQCOSM.

For more information concerning the research in this report,
contact the
Nevada Water Science Center
U.S. Geological Survey
2730 N. Deer Run Road
Carson City, Nevada, 89701
https://www.usgs.gov/centers/nv-water
Publishing support provided by the U.S. Geological Survey
Science Publishing Network, Sacramento Publishing Service Center 


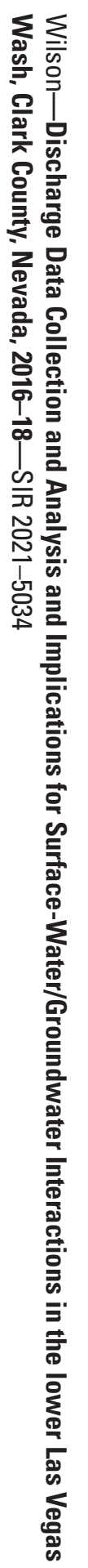

